\title{
Paying Attention: Overnight Returns and the Hidden Cost of Buying at the Open
}

\author{
Henk Berkman, Paul D. Koch, Laura Tuttle, and \\ Ying Jenny Zhang*
}

\begin{abstract}
We find a strong tendency for positive returns during the overnight period followed by reversals during the trading day. This behavior is driven by an opening price that is high relative to intraday prices. It is concentrated among stocks that have recently attracted the attention of retail investors, it is more pronounced for stocks that are difficult to value and costly to arbitrage, and it is greater during periods of high overall retail investor sentiment. The additional implicit transaction costs for retail traders who buy high-attention stocks near the open frequently exceed the effective half spread.
\end{abstract}

\section{Introduction}

Behavioral finance theories assume that individual investors are subject to sentiment that makes them willing to trade at prices not justified by fundamentals. Moreover, sentiment-driven retail traders tend to act as a group, trading the same stocks at the same time and in the same direction. Because trading against these investors can be costly and risky, the collective price impact of their trading can be substantial, and sentiment-based trading can cause prices to deviate from fundamental value for long periods of time. ${ }^{1}$

\footnotetext{
*Berkman, h.berkman@auckland.ac.nz, Business School, University of Auckland, 12 Grafton Rd, Auckland, New Zealand; Koch, pkoch@ku.edu, School of Business, University of Kansas, Summerfield Hall, Lawrence, KS 66045; Tuttle, 1tuttle@aus.edu, School of Business and Management, American University of Sharjah, PO Box 26666, Sharjah, United Arab Emirates; and Zhang, yjennyzhang@missouristate.edu, College of Business Administration, Missouri State University, 901 S National Ave, Springfield, MO 65897. We thank an anonymous referee, Chris Anderson, Audra Boone, Stephen Brown (the editor), Bob DeYoung, Laura Field, Ben Jacobsen, Kelly Welch, Jide Wintoki, and seminar participants at the University of Auckland, Massey University, the University of Kansas, the 2009 New Zealand Finance Colloquium, the Securities and Exchange Commission, and the national conferences of the Financial Management Association and the Eastern Finance Association for their helpful comments on earlier drafts. We thank Jeff Harris, Frank Hatheway, and NASDAQ OMX for access to proprietary data. We also thank Xin Zhao for excellent research assistance. In addition, Koch acknowledges support from the University of Auckland and Massey University, where he served as a visiting professor while conducting this research. Tuttle acknowledges research support from the Commodity Futures Trading Commission, where she served as a visiting economist.

${ }^{1}$ For theoretical work in this area, see De Long, Shleifer, Summers, and Waldmann (1990) and Shleifer and Vishny (1997). Kumar and Lee (2006) provide empirical evidence that herding by retail 
Barber and Odean (2008) contribute to this literature by theorizing that retail investors herd into attention-grabbing stocks. They observe that retail investors who want to buy face a different search problem than those who want to sell. When retail investors want to buy, they must select from thousands of stocks. Odean (1999) and Barber and Odean (2008) hypothesize that individual investors manage this problem by limiting their search to stocks that have recently attracted their attention. However, when retail investors want to sell, their decision of which stock to sell is normally limited to the small set of stocks they own, since retail investors typically do not sell short. Consistent with this theory, Barber and Odean show that individual investors are net buyers on the next trading day following days with high absolute returns, which is one of their proxies for attention.

We extend the theory of Barber and Odean (2008) to develop several predictions with regard to intraday patterns in retail order flow and price formation. Our 1st prediction is that an attention-triggering event on day $t$ will lead to retail buying near the open on day $t+1$, because the open is the 1 st opportunity since the previous close for retail investors to buy these high-attention stocks. ${ }^{2}$ Second, we hypothesize that this attention-driven retail buying pressure results in opening prices that are high relative to prices during the rest of the trading day, especially for stocks that are difficult to value and costly to arbitrage. Finally, we expect that the impact of attention on opening prices is greater during periods of high overall retail investor sentiment.

We test these predictions for the 3,000 largest U.S. stocks over the period from 1996 to 2008. In preliminary analysis, we examine quote midpoints at the open and close, and we find significant positive mean overnight returns of +10 basis points (bp) per day, along with negative trading day reversals of $-7 \mathrm{bp}$ per day. We then explore whether these overall tendencies are due to a high opening price, a low closing price, or both. Consistent with our theory of attentionbased overpricing at the open, we find that the opening price is high relative to subsequent intraday prices, while there is no tendency for the closing price to decline further below intraday prices. ${ }^{3}$

These descriptive results are consistent with evidence in two papers that were developed simultaneously with ours. Branch and Ma (2008) find a negative correlation between the overnight return and the subsequent trading day return. They suggest that this tendency may relate to the microstructure of how specialists and market makers behave at the open. Cliff, Cooper, and Gulen (2008) find evidence that the U.S. equity premium over the last decade is solely due to positive overnight returns. They observe that evidence of systematic negative daytime reversals "present(s) a serious challenge to traditional asset pricing models from

traders helps to explain returns for stocks with high retail concentration that are also difficult to arbitrage. Barber, Odean, and Zhu (2009) show that stocks bought by retail investors underperform stocks sold by retail investors over the following year. Baker and Wurgler (2006) find that, after periods of high (low) sentiment, stocks that are difficult to value and costly to arbitrage earn low (high) returns.

${ }^{2}$ There is an after-hours market and a pre-open on electronic communication networks (ECNs), but high costs and other impediments to trading deter retail investors, so that professional traders dominate these markets (see Barclay and Hendershott (2003), (2004)).

${ }^{3}$ Reliance on midquotes ensures that our results are not due to bid-ask bounce. Trade prices yield similar results. 
the standpoint that these models do not predict negative average returns." Both of these studies join our work to emphasize that this behavior represents a surprising new anomaly, and they call for further efforts to find an explanation. We extend the analysis and show that our theory of attention-triggered retail buying at the start of the trading day offers a unifying explanation for this behavior.

Empirical analysis of our theory requires a proxy for the level of retail investor attention at the start of the typical trading day. We use two size-adjusted market-based variables from the previous day. First, following Barber and Odean (2008), we consider the squared return yesterday as a proxy for news that could attract the attention of retail investors today. ${ }^{4}$ Second, motivated by the main result in Barber and Odean that individual investors are net buyers of attention-grabbing stocks, we use actual net buying by individual investors all day yesterday as a percent of total volume to proxy for retail attention at the start of trading today.

We obtain this 2nd proxy using proprietary data on the intraday trading activity of retail investors, for an abridged sample of NASDAQ stocks during 1997-2001..$^{5}$ These data also enable measurement of the intensity of net buying by retail investors near the open, relative to that during the rest of the trading day. Consistent with our 1st hypothesis, we find that i) the intensity of retail buying near the open is significantly greater for high-attention stocks than for lowattention stocks, and ii) the intensity of retail buying of high-attention stocks is significantly greater during the 1 st hour than it is during the rest of the trading day.

We next examine the implications of these intraday patterns in net retail buying for price formation at the open. When we analyze our main sample of the 3,000 largest U.S. stocks during 1996-2008, we find that the subsample of highattention stocks has a significant mean overnight return (trading day reversal) of $+13(-13)$ bp per day. In contrast, the analogous results for the subsample of low-attention stocks are much smaller, at only $+3(-3)$ bp per day. When we examine the abridged sample of NASDAQ stocks during 1997-2001, the mean overnight return (trading day reversal) for high-attention stocks is larger in magnitude, at $+26(-27)$ bp per day. Once again, the analogous results for low-attention NASDAQ stocks during this period are much smaller, at $+4(-12)$ bp per day. Importantly, the average 24-hour (close-to-close) return is never significantly different from 0 for any subsample examined. Together, these results support our 2nd hypothesis, indicating a significant price impact of attention-triggered retail buying pressure at the open, which is only a short-term intraday phenomenon.

Based on behavioral finance theories, we expect that stock prices may deviate further from fundamentals if the stock is more difficult to value and more costly to arbitrage. ${ }^{6}$ We test this hypothesis by extending our analysis in two ways. First, we consider the role of institutional ownership in concert with our proxies for

\footnotetext{
${ }^{4}$ In addition to absolute returns yesterday, Barber and Odean (2008) consider contemporaneous daily volume as an alternative measure of retail attention. We have also used share turnover yesterday to proxy for retail investor attention at today's open, and we find robust results.

${ }^{5}$ We are grateful to Jeff Harris, Frank Hatheway, and NASDAQ OMX for providing these proprietary data. See Griffin, Harris, and Topaloglu (2003) for details about the data.

${ }^{6}$ For example, see Baker and Wurgler (2006) and Kumar and Lee (2006).
} 
retail attention. Stocks with low institutional holdings have a high concentration of retail investors and are difficult to short sell. ${ }^{7}$ Thus, for these stocks, we expect greater upward price pressure at the open on days following news that attracts the attention of retail investors. Our results support this prediction. Now the subset of our main sample of stocks subject to both high attention and low institutional ownership has a larger mean overnight return (trading day reversal), at $+17(-17)$ bp per day. Similarly, the analogous stratification from our abridged sample of NASDAQ stocks also has a larger mean overnight return (trading day reversal), at $+34(-42)$ bp per day. In contrast, the subsample that is least prone to overpricing at the open, with low attention and high institutional ownership, has overnight returns and trading day reversals that lack economic or statistical significance.

Second, we show that these overnight return patterns increase in magnitude for finer subsamples of stocks that are more difficult to value and more costly to arbitrage. We analyze a subset of the main sample that includes only firms with high recent volatility, high transaction costs, and high short interest. For this subset, the mean overnight return (trading day reversal) for the finer subsample of stocks subject to both high attention and low institutional ownership is $+43(-45)$ bp per day. Likewise, the analogous results for the abridged sample of NASDAQ stocks are $+61(-70)$ bp per day.

The high opening prices we find for stocks subject to high attention and low institutional ownership represent a substantial hidden cost of buying at the open. Our tests are predictive and thus indicate that postponing purchases of these stocks from the open until later in the day can avoid these hidden costs. Similarly, selling these stocks at the open, rather than later in the day, can lead to major improvements in performance. For example, a mean trading day reversal of $45 \mathrm{bp}$ per day accumulates to $112.5 \%$ per annum.

Finally, we investigate whether the magnitude of positive overnight returns and negative trading day reversals is exacerbated during periods with high overall investor sentiment (see Baker and Wurgler (2006), (2007)). We consider 2 timeseries proxies that measure variation over time in the level of retail investor sentiment. Our 1st measure is the sentiment index of Baker and Wurgler (2006), while our 2 nd measure is based on market-wide net buying activity by retail investors during the 1 st hour of the trading day. We find that variation over time in the magnitude of opening price inflation, for stocks subject to high attention and low institutional holdings, is significantly related to both of these time-series indices of market sentiment. For example, mean overnight returns and trading day reversals are more than twice as large during months with high versus low sentiment. In addition, during periods of high investor sentiment, this opening price inflation can be twice the magnitude of the effective half spread. This evidence establishes that the behavior of overnight returns and trading day reversals documented in this study is both economically and statistically significant.

\footnotetext{
${ }^{7}$ Kumar and Lee (2006) show that retail trading is negatively correlated with institutional ownership. In addition, a large body of work uses low institutional ownership to proxy for binding short sale constraints (e.g., see Almazan, Brown, Carlson, and Chapman (2004), Asquith, Pathak, and Ritter (2005), Berkman, Dimitrov, Jain, Koch, and Tice (2009), D’Avolio (2002), Nagel (2005), and Ofek, Richardson, and Whitelaw (2004)).
} 
Our results are robust when we apply this portfolio approach using marketadjusted returns, median returns, or trade prices to measure returns, and when we exclude low-price stocks. This behavior is also ubiquitous across small and large stocks, NASDAQ and NYSE stocks, growth and value stocks, and momentum winners and losers, although there is a larger mean overnight return and trading day reversal for small stocks, NASDAQ stocks, growth stocks, and momentum losers. We also find that these patterns are largest on Mondays, but they also appear on the other days of the week. In addition, these results appear in all subperiods. Finally, we find similar results and conclusions when we apply an alternative Fama-MacBeth (1973) regression approach.

This article proceeds as follows: Section II describes our sample selection and variable construction. Section III reports descriptive statistics. Section IV presents the main empirical analysis. Section V analyzes the time-series relation between overall market sentiment and the magnitude of opening price inflation. Section VI provides robustness tests, and Section VII summarizes and concludes.

\section{Sample Selection and Variable Construction}

\section{A. Sample Selection and Daily Return Measures}

Our main sample includes the 3,000 largest U.S. firms, according to their market capitalization on July 1 of each year over the period from 1996 to 2008 . We also apply our analysis to an abridged sample for which proprietary data on intraday retail trading were obtained from NASDAQ OMX. These proprietary data describe each trade for NASDAQ stocks during the period from 1997 to 2001, and they include the identity of market participants on each side of the trade. For this abridged sample, we follow the procedures in Griffin et al. (2003) and classify both sides of all trades as originating from an individual or an institution based on the market participants involved in the trade.

We calculate daily returns using quotations from TAQ. ${ }^{8}$ The opening price on day $t\left(\mathrm{OPEN}_{t}\right)$ is the midpoint of the 1 st valid bid and ask quotes after 9:30AM. ${ }^{9}$ The closing price on day $t\left(\mathrm{CLOSE}_{t}\right)$ is the midpoint of the last valid bid and ask quotes before 4:00PM. ${ }^{10}$ We adjust these daily opening and closing prices for

\footnotetext{
${ }^{8}$ TAQ's consolidated quotation file is an aggregation of quotes within each market venue. It represents a set of "top of book" records for each venue. In order to identify market-wide best prices, we calculate an inside market across all venues. For the NYSE, this calculation almost never improves upon the NYSE specialist's price. However, in NASDAQ issues, ECNs often improve on the NASDAQ's reported best price.

${ }^{9}$ By "the first valid quotes" we mean the 1st quotes after 9:30AM for which there is nonzero trade size on both the bid and the ask. For NYSE issues, selection of the open is straightforward, since the opening cross is easily identified and begins the trading day. For NASDAQ issues, selection of the open is not so straightforward. Although technically the NASDAQ opens at 9:30AM, it is often several minutes before valid market-maker quotes appear. If the midquote precisely at 9:30 AM is used as the open, these quotes will often be flagged as "closed" by the market participant, or they may have 0 size associated with the prices. In either case, the price does not represent a firm commitment to trade. This behavior of the NASDAQ open motivates our choice of the 1st valid quotes after 9:30AM as the opening quotes. Our results are robust when we take the midquote precisely at 9:30AM as the open.

${ }^{10}$ Occasionally, the final quotes before 4:00PM have zero shares available to trade on one or both sides, or the quote is flagged as closed. For this reason, we select the last valid quote before 4:00PM.
} 
stock splits and dividends, before computing daily returns. ${ }^{11}$ Returns are measured as the log of the price relative over each time frame considered:

$$
\begin{aligned}
\text { 24-Hour, Open-to-Open Return } & =\mathrm{OTO}_{t}=\log \left(\mathrm{OPEN}_{t} / \mathrm{OPEN}_{t-1}\right) \\
\text { 24-Hour, Close-to-Close Return } & =\mathrm{CTC}_{t}=\log \left(\mathrm{CLOSE}_{t} / \mathrm{CLOSE}_{t-1}\right) ; \\
\text { Overnight, Close-to-Open Return } & =\mathrm{CTO}_{t}=\log \left(\mathrm{OPEN}_{t} / \mathrm{CLOSE}_{t-1}\right) ; \\
\text { Trading Day, Open-to-Close Return } & =\mathrm{OTC}_{t}=\log \left(\mathrm{CLOSE}_{t} / \mathrm{OPEN}_{t}\right) .
\end{aligned}
$$

Note that $\mathrm{CTC}_{t}=\mathrm{CTO}_{t}+\mathrm{OTC}_{t}$. Finally, consistent with prior work, we screen the data for errors and extreme observations. ${ }^{12}$

\section{B. Variable Construction}

For each stock, we estimate 2 proxies for the level of attention by retail investors at the start of the trading day. Our 1st proxy is the square of yesterday's close-to-close return $\left(\mathrm{VOL}_{t-1}\right)$. This measure is motivated by Barber and Odean (2008), who use the absolute return yesterday to proxy for news that could attract the attention of retail investors, and who find that increases in this measure are associated with increases in net retail buying throughout today. Our 2nd proxy is net shares bought by individual investors yesterday, as a percent of total daily share volume (RETAIL_NETBUY $t_{-1}$ ). This measure is also motivated by the results in Barber and Odean. Their finding that individual investors are net buyers of attention-grabbing stocks suggests that stocks with high net retail buying have (almost by definition) attracted the attention of retail investors.

We also use the abridged sample of NASDAQ stocks over the period from 1997 to 2001 to compute 3 measures of the intensity of net buying by retail investors near the day's open:

$$
\begin{aligned}
& \text { NetBuy_Open }_{t}=\text { the mean proportion of stocks on day } t \text { for which } \\
& \text { the } 1 \text { st trade of the day is a purchase by a retail } \\
& \text { investor, minus 0.5; } \\
& \text { NetBuy_15Min }{ }_{i t}=(\text { Net Retail Buy Volume in 1st } 15 \mathrm{~min}) / \\
& \text { (Total Retail Volume in } 1 \text { st } 15 \text { min); } \\
& \text { NetBuy_DIFF }_{i t}=[(\text { Net Retail Volume in } 1 \mathrm{st} \text { hour })-(\text { Net Retail } \\
& \text { Volume in last } 5.5 \text { hours / 5.5)]/(shares outstanding); }
\end{aligned}
$$

\footnotetext{
${ }^{11}$ On days when a cash dividend or a stock split becomes effective at the open, we adjust the TAQ data on opening and closing prices using Center for Research in Security Prices (CRSP) data on the amount of the cash dividend or the multiple of the stock split. The adjusted opening and closing prices are then used to compute each daily return measure.

${ }^{12}$ Quotes are dropped from our analysis if their "mode" designation indicates that they are not normal quotes, or if the reported ask price is greater than 1.5 times the reported bid price. In addition, we omit the daily return if i) the bid-ask spread at the open or close is negative, ii) the opening or closing spread is greater than $\$ 5.00$ or $30 \%$ of the midpoint quote, iii) the effective half spread is greater than $\$ 2.50$ or $15 \%$ of the midpoint quote, or iv) the daily open is more than $25 \%$ greater (or less) than both the previous close and the subsequent close. We also drop all daily returns for a firm if daily quotes are missing for more than $25 \%$ of all trading days for that firm.
} 
where Net Retail Buy Volume ${ }_{i t}=$ the net number of shares of stock $i$

bought by retail investors over

each time frame, on day $t$;

and Total Retail Volume ${ }_{i t}=$ the total number of shares of stock $i$

traded by retail investors over

each time frame, on day $t$.

The 1st variable defined previously measures the "net" tendency for the 1st trade of the day to be a purchase by a retail investor. The next variable reflects the flow of net purchase volume by retail investors as a percent of total retail share volume over the first 15 minutes of the trading day. The last variable captures the difference between the rate of net retail buying during the 1st hour and the hourly rate of net retail buying during the rest of the trading day, as a percent of shares outstanding. ${ }^{13}$

Next, following Asquith et al. (2005), we consider 2 proxies for short sale constraints: institutional ownership and relative short interest. Data on institutional holdings are from CDA Spectrum $13 \mathrm{~F}$ filings. Each quarter, we compute the percentage institutional ownership ( $\mathrm{INST}_{t}$ ) for every firm as aggregate shares held by institutions scaled by shares outstanding. If a stock is available in CRSP but has no information on institutional holdings, we assume that the stock has zero institutional ownership (see Asquith et al. (2005), Gompers and Metrick (2001), and Nagel (2005)). Our 2nd proxy for short sale constraints is relative short interest $\left(\mathrm{RSI}_{t}\right)$, measured by the total number of shares sold short as a percent of shares outstanding, using monthly data on short interest from the NYSE and the NASDAQ.

Finally, we use 3 measures of transaction costs: the percentage spread at the open $\left(\operatorname{SPR}(\mathrm{OPEN})_{t}\right)$ and at the close $\left(\mathrm{SPR}(\mathrm{CLOSE})_{t}\right)$ and the percentage effective half spread $\left(\operatorname{SPREAD}_{t}\right) \cdot{ }^{14}$

\section{Descriptive Statistics and Intraday Price Patterns}

\section{A. Descriptive Statistics for Overnight Returns and Trading Day Returns}

In Panel A of Table 1, we report the mean and median values for overnight returns, trading day returns, and 24-hour returns across all firms and days in the sample. Note that the average number of firms each day varies from 2,447 to 2,604 across the different measures of daily returns considered. This number is less than the 3,000 largest U.S. stocks used as the initial sample, because daily opening or

\footnotetext{
${ }^{13}$ We have also analyzed net retail buy volume over the 1 st minute and the first 5 minutes of the trading day. Analysis of these variables yields similar results to the measures defined here.

${ }^{14}$ For every trade, the percentage effective half spread is defined as the absolute difference between the trade price and the quote midpoint, as a percent of the quote midpoint. Trades are matched to quotes with a lag of 1 second and then averaged to get the day's percentage effective half spread. Our choice of a 1-second lag is taken from the NASDAQ Economic Research Office, which argues that this lag is optimal to match trades and quotes in its automated electronic system. Our results are not affected by this choice (see Lee and Ready (1991), Bessembinder (2003)).
} 
closing quotes are sometimes invalid or unavailable for some of the smaller stocks (see footnote 12 for details of our screening procedure).

Standard $t$-tests applied to these mean returns could be biased due to crosscorrelation of daily returns across firms on the same date (Bernard (1987)). In our analysis we adjust our standard errors for this possibility. Specifically, for each of the 3,268 trading days in our 13-year sample period, we first compute the cross-sectional mean (or median) overnight and trading day returns across all stocks in the sample. We then compute the time-series average of these crosssectional mean (or median) returns across all trading days in the sample period. The corresponding $t$-statistics are based on the standard errors of the time-series mean returns.

Results on the left side of Panel A in Table 1 indicate a significant positive mean overnight return (CTO) of approximately +10 bp per day, and a significant negative trading day reversal (OTC) of -7 bp per day, when averaged across all firms and days. As a result, the mean return on a strategy that is long the sample stocks during the overnight period and short the same stocks during the subsequent trading day (DIFF) would be +17 bp per day, before deducting transaction costs. On the other hand, when we subtract the average bid-ask spread at the daily

TABLE 1

\title{
Descriptive Statistics and Correlations across Variables
}

\begin{abstract}
We apply our analysis to 2 major samples. Our main analysis is applied to the subsample of the 3,000 largest U.S. stocks each year with nonmissing TAQ data on quotes, over the 13-year period 1996-2008. We also analyze an abridged sample of all NASDAQ firms for which data on intraday retail trading activity are available, over the period 1997-2001. The focus of this study is on percentage overnight and trading day returns, measured as $100 \times$ the log of the price relative using quote midpoints at the open and the close: CTO = close-to-open (overnight) return and OTC = open-to-close (trading day) return. We also analyze the difference between overnight and trading day returns (DIFF = CTO - OTC), as well as this same difference after deducting transaction costs measured as the average spread at the day's open and close: DIFF - TC = DIFF - [SPR(OPEN) + SPR(CLOSE)] / 2. In addition, we examine daily returns measured over the 24-hour periods from close-to-close and from open-to-open: CTC and OTO. We consider 2 alternative proxies for retail investor attention: i) $\mathrm{VOL}_{t-1}=$ the squared 24-hour (close-to-close) return yesterday, and ii) RETAIL_NETBUY ${ }_{t-1}=$ the net number of shares bought by retail investors yesterday, as a percent of total share volume. Next, we compute 3 measures of the intensity of net retail buying near the open: NetBuy Open $=$ the mean proportion of stocks each day for which the 1st trade of the day is a purchase by a Retail Trader, minus 0.5; NetBuy_15Min = (Net Retail Buy Volume) / (Total Retail Share Volume), over the first 15 minutes of the trading day; NetBuy_Diff = [(Net Retail Buy Volume in 1st Hour) - (Net Retail Buy Volume in Last 5.5 Hours / 5.5)] / (shares outstanding). The last measure defined above represents the difference between the hourly rate of net buying by retail investors during the 1st hour of trading and the analogous hourly rate during the rest of the trading day, as a percent of shares outstanding. We also consider 2 proxies for short sale constraints and 3 measures of transaction costs. Our 2 proxies for short sale constraints are i) the percent of institutional ownership (INST), and ii) relative short interest (RSI), measured as the number of shares sold short each month divided by shares outstanding. Our 3 measures of daily transaction costs include i) the bid-ask spread as a percent of the quote midpoint at the open (SPR(OPEN)), ii) the analogous percent spread at the close (SPR(CLOSE)), and iii) the daily effective half spread (SPREAD). Finally, firm size (SIZE) is proxied by daily market capitalization. The descriptive statistics in Panels A and $\mathrm{B}$ are calculated by first computing the cross-sectional mean (or median) each day, and then averaging these means (or medians) across all days in the sample period. The standard deviation of the time-series average across daily means is then used to construct the $t$-test for each statistic in Panels A and B. Similarly, the Spearman correlations in Panel C are calculated by first computing the cross-sectional correlation each day, and then averaging these correlations across all days in the sample. Once again, the standard deviation of the time-series average correlation is used to construct the $t$-test for each average correlation in Panel C. ${ }^{*}$ and ${ }^{* *}$ indicate significance at the $5 \%$ and $1 \%$ levels, respectively.

Panel A. Descriptive Statistics for Overnight (Close-to-Open) Returns, Trading Day (Open-to-Close) Returns, and 24-Hour Returns
\end{abstract}

Overnight and Trading Day Returns

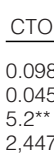

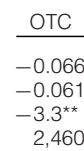

DIFF

0.165

0.108

$6.1^{\star \star}$

2,447

$$
\begin{gathered}
\text { DIFF - TC } \\
\hline-0.708 \\
-0.618 \\
-24.8^{\star \star} \\
2,383
\end{gathered}
$$

24-Hour Returns

\begin{tabular}{cc}
\hline CTC & OTO \\
0.031 & \\
-0.016 & -0.028 \\
1.1 & 1.2 \\
2,447 & 2,604 \\
(continued on next page)
\end{tabular}


TABLE 1 (continued)

Descriptive Statistics and Correlations across Variables

\begin{tabular}{|c|c|c|c|c|c|c|c|c|c|c|c|}
\hline & \multicolumn{2}{|c|}{ Proxies for Attention } & \multicolumn{3}{|c|}{ Net Retail Buying Near the Open } & \multicolumn{2}{|c|}{ Short Sale Constraints } & \multicolumn{3}{|c|}{ Transaction Costs } & \multirow{2}{*}{$\begin{array}{l}\text { Firm Size } \\
\text { SIZE }(\$ 000)\end{array}$} \\
\hline & $\mathrm{VOL}_{t-1}$ & $\begin{array}{c}\text { RETAIL_- } \\
\text { NETBUY } \\
\text { NET-1 } \\
\end{array}$ & $\begin{array}{c}\text { 1st } \\
\text { Trade } \\
\text { NetBuy_- } \\
\text { Open } \\
\end{array}$ & $\begin{array}{c}\text { 1st } \\
\text { 15-Min } \\
\text { NetBuy- } \\
\text { 15Min } \\
\end{array}$ & $\begin{array}{c}\text { (1st Hour - } \\
\text { Rest) } \\
\text { NetBuy- } \\
\text { DIFF } \\
\end{array}$ & INST & RSI & $\begin{array}{c}\text { SPR } \\
\text { (OPEN) } \\
\end{array}$ & $\begin{array}{c}\text { SPR } \\
\text { (CLOSE) } \\
\end{array}$ & $\underline{\text { SPREAD }}$ & \\
\hline \multicolumn{12}{|c|}{ Panel B. Descriptive Statistics for Attention, Net Retail Buying Near the Day's Open, Short Sale Constraints, Transaction Costs, and Firm Size } \\
\hline Mean (\%) & 0.127 & 0.000 & 0.004 & 0.024 & 0.025 & 0.520 & 0.038 & 1.057 & 0.619 & 0.173 & $5,210,818$ \\
\hline Median (\%) & 0.059 & 0.136 & 0.052 & 0.038 & 0.004 & 0.532 & 0.022 & 0.724 & 0.407 & 0.123 & $1,109,367$ \\
\hline$T\left(\mathrm{H}_{0}:\right.$ Mean $\left.=0\right)$ & $31.3^{\star \star}$ & -0.3 & $3.4^{\star \star}$ & $15.4^{\star \star}$ & $26.2^{* *}$ & $214.6^{\star \star}$ & $101.1^{\star \star}$ & $83.6^{\star \star}$ & $68.3^{\star \star}$ & $81.1^{\star \star}$ & $175.8^{\star \star}$ \\
\hline Avg. no. of firms per day & 2,602 & 401 & 161 & 310 & 400 & 2,681 & 2,681 & 2,616 & 2,619 & 2,463 & 2,534 \\
\hline \multicolumn{12}{|c|}{ Panel C. Spearman Correlations } \\
\hline $\mathrm{VOL}_{t-}$ & 1.000 & & & & & & & & & & \\
\hline RETAIL_NETBUY $Y_{t-1}$ & $0.062^{\star \star}$ & 1.000 & & & & & & & & & \\
\hline NetBuy_Open & 0.002 & $0.038^{* *}$ & 1.000 & & & & & & & & \\
\hline NetBuy_15Min & $0.004^{\star \star}$ & $0.085^{\star *}$ & $0.465^{\star \star}$ & 1.000 & & & & & & & \\
\hline NetBuy_DIFF & $0.027^{\star \star}$ & $0.051^{\star *}$ & $0.135^{\star \star}$ & $0.369^{\star \star}$ & 1.000 & & & & & & \\
\hline $\begin{array}{l}\text { INST } \\
\text { RSI }\end{array}$ & $\begin{array}{l}0.082^{\star *} \\
0.358^{\star *}\end{array}$ & $0.004^{* *}$ & $0.006^{\star \star}$ & $0.010^{* *}$ & $0.025^{\star *}$ & 1.000 & & & & & \\
\hline RSI & $0.358^{\star \star}$ & $0.044^{\star \star}$ & $0.006^{\star \star}$ & 0.003 & $0.034^{\star *}$ & $0.390^{* *}$ & 1.000 & & & & \\
\hline SPR(OPEN) & $0.173^{\star \star}$ & $-0.027^{* \star}$ & $-0.006^{\star *}$ & $-0.009^{* \star}$ & $-0.043^{\star *}$ & $-0.136^{\star \star}$ & $-0.073^{* *}$ & 1.000 & & & \\
\hline $\begin{array}{l}\text { SPR(CLOSE) } \\
\text { SPREAD }\end{array}$ & $\begin{array}{l}0.158^{\star \star} \\
0.332^{\star \star}\end{array}$ & $\begin{array}{l}-0.025^{\star \star} \\
-0.021^{* \star}\end{array}$ & $\begin{array}{l}-0.005^{\star \star} \\
-0.001\end{array}$ & $\begin{array}{l}-0.007^{\star \star} \\
-0.008^{\star *}\end{array}$ & $\begin{array}{l}-0.044^{\star \star} \\
-0.052^{\star \star}\end{array}$ & $\begin{array}{l}-0.189^{\star \star} \\
-0.283^{\star \star}\end{array}$ & $\begin{array}{l}-0.126^{* *} \\
-0.084^{* *}\end{array}$ & $\begin{array}{l}0.465^{\star \star} \\
0.569^{\star \star}\end{array}$ & $\begin{array}{l}1.000 \\
0.570^{\star \star}\end{array}$ & & \\
\hline SIZE & $-0.223^{\star \star}$ & $0.030^{* *}$ & 0.001 & $0.009^{* *}$ & $0.051^{* *}$ & $0.163^{* *}$ & 0.008 & $-0.563^{\star \star}$ & $-0.531^{\star \star}$ & $-0.705^{\star *}$ & 1.000 \\
\hline СТО & $0.055^{\star \star}$ & $0.058^{* *}$ & $0.038^{\star \star}$ & $0.028^{\star \star}$ & $0.016^{\star *}$ & $-0.011^{\star \star}$ & $0.020^{\star \star}$ & $0.021^{* *}$ & $0.006^{\star \star}$ & $0.020^{\star *}$ & $-0.017^{\star \star}$ \\
\hline OTC & $-0.044^{\star \star}$ & $-0.020^{\star \star}$ & 0.000 & $-0.006^{* *}$ & $0.051^{* *}$ & $0.009^{\star *}$ & $-0.023^{* *}$ & $-0.005^{\star *}$ & $-0.018^{\star \star}$ & $-0.024^{\star *}$ & $0.029^{* *}$ \\
\hline DIFF & $0.056^{\star \star}$ & $0.037^{\star \star}$ & $0.011^{\star \star}$ & $0.011^{\star \star}$ & $-0.045^{\star \star}$ & $-0.011^{\star \star}$ & $0.027^{\star \star}$ & $0.009^{* *}$ & $0.017^{\star *}$ & $0.025^{* *}$ & $-0.028^{\star *}$ \\
\hline DIFF - TC & 0.000 & $0.037^{\star \star}$ & $0.010^{\star \star}$ & $0.011^{\star \star}$ & $-0.040^{\star \star}$ & $0.040^{* *}$ & $0.061^{\star \star}$ & $-0.203^{\star \star}$ & $-0.166^{\star \star}$ & $-0.134^{\star \star}$ & $0.119^{* \star}$ \\
\hline
\end{tabular}


open and close, we obtain a significant negative mean difference after transaction costs (DIFF - TC) of $-71 \mathrm{bp}$. Note that the median value of the overnight return in Panel A of Table 1 (CTO) is somewhat smaller than the mean, while the median trading day return in Panel A (OTC) is approximately the same as the mean. Finally, the 24-hour return (i.e., the sum of CTO and OTC) is close to 3 bp per day, which corresponds to around $8 \%$ per annum.

\section{B. Descriptive Statistics for the Main Variables}

Panel B of Table 1 provides descriptive statistics for the main variables in the study. First consider our 2 proxies for retail attention. The average squared close-to-close return $\left(\mathrm{VOL}_{t-1}\right)$ is $0.127 \%$, while the mean daily retail net buying (RETAIL_NETBUY ${ }_{t-1}$ ) is not significantly different from 0 . The latter result indicates that, during the 1997-2001 sample period, there was no substantive shift in ownership of NASDAQ stocks between retail and institutional investors.

Next we present 3 measures of the intensity of retail net buying near the day's open (NetBuy_Open, NetBuy_15Min, and NetBuy_DIFF). These mean values are significantly positive, indicating that retail investors tend to be net buyers of stocks at the open, and during the first 15 minutes of the trading day. In addition, the rate of net retail buying in the 1st hour is significantly greater than the analogous hourly rate over the rest of the trading day.

Finally, consider our measures of short sale constraints and transaction costs. We find that mean institutional ownership (INST) is 52\% of shares outstanding. This number is higher than the $34 \%$ reported in Nagel (2005), because our sample is limited to larger firms. Relative short interest averages $3.8 \%$ of shares outstanding across all stocks and days in the sample, similar to that reported in Asquith et al. (2005). The average spread at the open is $1.06 \%$ of the quote midpoint, while the average spread at the close is $0.62 \%$, and the mean effective half spread is $0.17 \%$. Finally, the average firm has a market capitalization of $\$ 5.21$ billion. Note that the medians for several variables in Panel B are smaller than their corresponding means, indicating some degree of positive skewness for these firm attributes.

\section{Correlations across the Main Variables}

In Panel $\mathrm{C}$ of Table 1 we report the average Spearman correlation across each pair of variables. ${ }^{15}$ These correlations are generally consistent with our expectations. First, note that our 2 proxies for retail investor attention have a significant positive correlation of $6 \%$. Second, both proxies are positively correlated with our measures of net retail buying pressure near the open. Third, both attention measures are positively correlated with the overnight return (CTO), and negatively correlated with the trading day return (OTC). All of this evidence is consistent with an upwardly biased opening price for stocks that are subject to higher attention by retail investors.

\footnotetext{
${ }^{15}$ Spearman correlations are applied to reduce the influence of outliers. Pearson correlations yield similar results.
} 
Fourth, consider the association between our proxies for short sale constraints and stock returns during the overnight period versus the trading day period. The percent of institutional ownership (INST) is significantly and negatively correlated with the overnight return (CTO) and positively correlated with the trading day return (OTC), while the opposite tendencies are apparent for RSI. This outcome suggests that stocks subject to more binding short sale constraints (i.e., with lower institutional ownership or higher short interest) tend to have larger overnight returns and trading day reversals. This result is also consistent with predictions based on our theory of attention-based overpricing at the open.

Fifth, the spread measures are positively correlated with the overnight return and negatively correlated with the trading day return, indicating a tendency for larger overnight returns and trading day reversals for stocks with higher transaction costs. In addition, the spread measures are negatively correlated with firm size and institutional holdings, as expected.

Finally, firm size is negatively related to overnight returns (OTC) and positively related to trading day returns (CTO). This outcome suggests that smaller firms have a tendency for larger positive overnight returns and trading day reversals. In addition, firm size is negatively correlated with one of our attention proxies $\left(\mathrm{VOL}_{t-1}\right)$ and positively correlated with institutional ownership (INST) and our 2nd attention proxy (RETAIL_NETBUY ${ }_{t-1}$ ). This evidence reinforces the need to control for size when we analyze the influence of institutional ownership or retail investor attention on daily returns in our analysis (see Nagel (2005)).

\section{The Intraday Price Pattern}

The descriptive statistics in Table 1 raise the question of whether this average positive overnight return and negative trading day reversal are due to a high opening price, a low closing price, or both. We address this issue by examining the pattern in prices throughout the trading day. For each stock, we collect data on intraday midquotes at 30-minute intervals. In addition, we gather the midquotes at 5-minute intervals during the first and last 30 minutes of the trading day. Then, at each 5- or 30-minute interval $(T)$, we construct the ratio of the midquote at that time to the day's closing midquote. ${ }^{16}$ We then find the average of each intraday price ratio across all stocks every day. Finally, we compute the time-series mean of these cross-sectional average price ratios for all days in the sample period.

Figure 1 plots the intraday pattern in this average ratio of the midquote at each intraday time $T$ to the closing midquote, across all stocks and days in the sample, along with the $95 \%$ confidence interval about a ratio of 1 . Note that this confidence interval collapses to 0 at the close, when the price ratio equals 1 for all firms. This intraday price pattern reveals that, on average, the opening price is significantly higher than the closing price by approximately $8 \mathrm{bp}$ (i.e., the opening price ratio $=1.0008$ ). After the open, the price declines during the first 60 minutes of trading to within the $95 \%$ confidence interval about 1 and then levels off during

\footnotetext{
${ }^{16}$ We choose the closing price to scale intraday price ratios because our main analysis focuses on open-to-close and close-to-open returns. Scaling by the average midquote between $11 \mathrm{AM}$ and $3 \mathrm{PM}$ yields similar results.
} 


\section{FIGURE 1}

Intraday Price Pattern: Ratio of Midquote at Intraday Time $(T)$ to the Closing Midquote across the 3,000 Largest U.S. Stocks and All Days (1996-2008)

This intraday price pattern traces out the ratio of the midquote at different times $(T)$ during the trading day, relative to the closing midquote. These intraday price ratios are computed for each stock at 5-minute intervals over the first and last 30 minutes of the trading day, and at 30-minute intervals over the rest of the trading day. First, for each day we average this price ratio at every intraday time $(T)$ across all stocks in the sample. Second, we compute the time-series mean of these daily cross-sectional averages across all days in the sample period. The $95 \%$ confidence interval about a ratio of 1.0 is constructed using the standard error of the time-series mean across all days, at each time $(T)$.

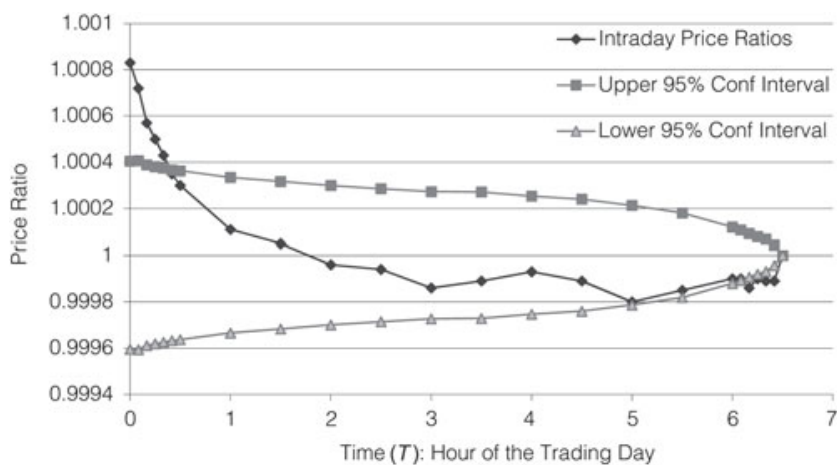

the middle of the day, before rising somewhat during the last few minutes of trading. This intraday pattern is consistent with the implications of our attentionbased explanation, indicating that prices near the open tend to be high relative to subsequent intraday prices. ${ }^{17}$

\section{Main Empirical Tests}

\section{A. Investor Attention and the Intensity of Net Retail Buying Near the Open}

Our 1st hypothesis is that high-attention days are followed by high net retail buying at the start of the next trading day. We test this hypothesis by comparing our 3 measures of the intensity of net retail buying near the open (NetBuy_Open, NetBuy_15Min, and NetBuy_DIFF) across portfolios partitioned by our proxies for attention, while controlling for firm size. These results appear in the first 3 columns of Table 2 .

In this approach we consider each trading day as a separate event. For each day, we control for firm size by initially sorting all firms into size terciles, based on the firm's mean market capitalization over the previous 20 trading days. ${ }^{18}$ Then, within each size tercile, we form 3 finer portfolios by independently sorting based on each proxy for attention: $\mathrm{VOL}_{t-1}$ or RETAIL_NETBUY $t-1$. Our size-adjusted

\footnotetext{
${ }^{17}$ In tests not reported here, we investigate whether overnight liquidity risk can explain these overnight return patterns, in the spirit of Acharya and Pedersen (2005) and Pastor and Stambaugh (2003). According to this theory, investors are willing to pay less at the daily close for stocks subject to greater overnight liquidity risk, measured by a stock's sensitivity to overnight changes in market liquidity. We find no evidence that stocks with greater overnight liquidity risk have lower closing prices, or greater overnight returns.

${ }^{18}$ Results are robust when we do not control for size in this partitioning scheme.
} 


\section{TABLE 2}

Net Retail Buying Near the Open of the Trading Day, Overnight Returns, Trading Day Returns, and 24-Hour Returns across Portfolios Sorted by Our 2 Proxies for Retail Investor Attention: Return Volatility and Net Retail Buying Yesterday

Columns 1 and 2 of Table 2 present information about the intensity of net retail buying at the open and during the first 15 minutes of the trading day, respectively:

(Column 1) NetBuy_Open $=\quad \begin{aligned} & \text { the mean proportion of stocks each day for which the 1st trade of the day is a } \\ & \text { purchase by a Retail Trader, minus 0.5. }\end{aligned}$
(Column 2) NetBuy_15Min $=\begin{aligned} & \text { (Net Retail Buy Volume) / (Total Retail Share Volume), over the first } 15 \text { minutes } \\ & \text { of the trading day. }\end{aligned}$

In column 3 we report the difference between the hourly rate of net buying by retail investors during the 1st hour of trading and the analogous hourly rate during the rest of the trading day, as a percent of shares outstanding. This measure is defined as follows:

$$
\begin{aligned}
\text { (Column 3) NetBuy_DIFF = } \quad & {[(\text { Net Retail Buy Volume in 1st Hour })} \\
& -(\text { Net Retail Buy Volume in Last } 5.5 \text { Hours } / 5.5)] / \text { (shares outstanding })
\end{aligned}
$$

In columns 4-6, we give the mean returns over 3 time frames: overnight (close-to-open (CTO)), trading day (open-to-close (OTC)), and 24 hours (close-to-close (CTC)). We report all of these measures for a $3 \times 1$ scheme of portfolios where stocks are partitioned each day into terciles by the level of retail investor attention. For every portfolio, we first compute the mean value of each measure across firms every day, and then average these cross-sectional means across all days in the sample. ${ }^{*}$ and ${ }^{* *}$ indicate significance at the $5 \%$ and $1 \%$ levels, respectively. ${ }^{\text {a }}$ These measures of net retail buying near the open are computed for all NASDAQ stocks (1997-2001).

Panel A. Using Return Volatility Yesterday $\left(V O L_{t-1}\right)$ to Proxy for Retail Investor Attention: 3,000 Largest U.S. Stocks

\begin{tabular}{|c|c|c|c|c|c|c|}
\hline & 1 & 2 & 3 & 4 & 5 & 6 \\
\hline Attention & $\begin{array}{c}\text { NetBuy_Opena } \\
\text { 1st Trade }\end{array}$ & $\begin{array}{l}\text { NetBuy_15Mina } \\
\text { 1st 15-Min }\end{array}$ & $\begin{array}{c}\text { NetBuy_DIFFa } \\
\text { (1st Hour - Rest) }\end{array}$ & $\begin{array}{l}\text { Overnight } \\
\text { CTO }\end{array}$ & $\begin{array}{c}\text { Trading Day } \\
\text { OTC }\end{array}$ & $\begin{array}{l}\text { 24-Hour } \\
\text { CTC }\end{array}$ \\
\hline Low & -0.003 & $0.018^{* *}$ & 0.014 & $0.030^{\star \star}$ & -0.030 & 0.000 \\
\hline Medium & 0.002 & $0.022^{\star \star}$ & 0.021 & $0.040^{\star \star}$ & $-0.050^{\star}$ & 0.000 \\
\hline High & $0.012^{\star \star}$ & $0.030^{\star \star}$ & $0.045^{\star *}$ & $0.130^{\star \star}$ & $-0.130^{\star \star}$ & 0.010 \\
\hline High - Low & 0.015 & 0.012 & 0.031 & 0.110 & -0.100 & 0.010 \\
\hline t-statistic & $6.2^{\star \star}$ & $4.3^{\star \star}$ & $10.9^{\star \star}$ & $7.7^{\star \star}$ & $-3.1^{\star \star}$ & 0.1 \\
\hline
\end{tabular}
(1997-2001)

Panel B. Using Retail Net Buying Yesterday (RETAIL_NETBUY I-1 $_{-}$) to Proxy for Retail Investor Attention: NASDAQ

\begin{tabular}{|c|c|c|c|c|c|c|}
\hline & 1 & 2 & 3 & 4 & 5 & 6 \\
\hline Attention & $\begin{array}{c}\text { NetBuy_Open } \\
\text { 1st Trade }\end{array}$ & $\begin{array}{l}\text { NetBuy_15Min } \\
\text { 1st 15-Min }\end{array}$ & $\begin{array}{c}\text { NetBuy_DIFF } \\
\text { (1st Hour - Rest) }\end{array}$ & $\begin{array}{l}\text { Overnight } \\
\text { CTO }\end{array}$ & $\begin{array}{c}\text { Trading Day } \\
\text { OTC }\end{array}$ & $\begin{array}{l}\text { 24-Hour } \\
\text { CTC }\end{array}$ \\
\hline Low & 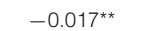 & $-0.034^{\star *}$ & $-0.004^{\star *}$ & $0.040^{*}$ & $-0.120^{*}$ & -0.080 \\
\hline Medium & $0.004^{*}$ & $0.024^{\star \star}$ & $0.020^{\star \star}$ & $0.160^{\star \star}$ & $-0.160^{\star \star}$ & 0.000 \\
\hline High & $0.024^{* *}$ & $0.079^{\star \star}$ & $0.060^{\star *}$ & $0.260^{\star \star}$ & $-0.270^{\star \star}$ & 0.000 \\
\hline High - Low & 0.041 & 0.113 & 0.064 & 0.220 & -0.150 & 0.070 \\
\hline t-statistic & $18.8^{* *}$ & $37.4^{\star \star}$ & $24.3^{\star \star}$ & $6.8^{\star \star}$ & $-2.1^{*}$ & 0.7 \\
\hline
\end{tabular}
Stocks (1997-2001)

high-attention portfolio each day thus contains the top $1 / 3$ of stocks by either attention proxy, within each size tercile. We then compute the cross-sectional means of our 3 measures of the intensity of net retail buying near the open, for each portfolio based on low, medium, or high size-adjusted retail investor attention. Finally, we average these cross-sectional means across all days in the sample period. The $t$-statistics are based on the Newey-West (1987) adjusted standard errors of the time-series means.

The first 3 columns in Panel A of Table 2 present our 3 measures of the average intensity of net retail buying near the open, for portfolios based on low, medium, or high attention, where the level of retail investor attention is proxied by return volatility yesterday $\left(\mathrm{VOL}_{t-1}\right)$. The first 3 columns of Panel B present the analogous results using net retail buying yesterday (RETAIL_NETBUY ${ }_{t-1}$ ) 
to proxy for attention. In both Panels A and B, all 3 measures are significantly positive for the subsample of high-attention stocks. Furthermore, the difference of means across portfolios with high versus low attention is always significantly positive at the $1 \%$ level. Together, these results confirm our 1st hypothesis, indicating that i) the intensity of retail buying near the open of the trading day is significantly greater for high-attention stocks than for low-attention stocks, and ii) the intensity of retail buying of high-attention stocks is significantly greater during the 1 st hour than it is during the rest of the trading day. ${ }^{19}$

\section{B. Investor Attention and Overnight and Trading Day Returns}

Our 2nd hypothesis predicts that this attention-triggered retail buying pressure at the open should result in opening prices that are high relative to prices during the rest of the trading day. We test this hypothesis by comparing the overnight and trading day returns across portfolios based on low, medium, or high attention. Results appear in the next 2 columns of Table 2.

Panels A and B of Table 2 both reveal a strong tendency for positive mean overnight returns and negative trading day reversals, which increase in magnitude and significance as we consider stocks subject to higher levels of attention. In Panel A, when we analyze the main sample of the 3,000 largest U.S. stocks, we find that the mean overnight return (trading day reversal) for the high-attention portfolio is $+13 \mathrm{bp}(-13 \mathrm{bp}$ ) per day. In contrast, the analogous results for the subsample of low-attention stocks in Panel A are much smaller, at only $+3(-3)$ bp per day. In Panel B, when we analyze the abridged sample of NASDAQ stocks, the analogous results for the high-attention portfolio are larger in magnitude, averaging $+26(-27)$ bp per day. Once again, the subsample of low-attention NASDAQ stocks in Panel B has much smaller means, at $+4(-12)$ bp per day. In both panels, the mean difference $t$-test indicates that the overnight return (trading day reversal) is significantly larger for the portfolio of stocks subject to high retail attention.

Finally, it is noteworthy that the mean 24-hour close-to-close return in the last column of Table 2 is not significantly different from 0 for any portfolio in Panels A or B. This result indicates that the significant overnight return patterns in Panels A and B represent a temporary mispricing at the open, which tends to be corrected during the course of the typical trading day.

\section{Investor Attention, Overnight and Trading Day Returns, and Institutional Ownership}

In this section we consider the role of institutional ownership in concert with our proxies for retail investor attention. Stocks with low institutional ownership necessarily have a high concentration of retail investors and are also difficult to short sell. For these stocks, we expect greater upward price pressure at the open on days following news that attracts the attention of retail investors (proxied by yesterday's return volatility or net retail buying). We test this hypothesis

\footnotetext{
${ }^{19}$ Using net retail buy volume over the 1 st minute or the first 5 minutes of the trading day yields robust results.
} 
by expanding our portfolio approach to compare average overnight and trading day returns across portfolios of firms that are independently partitioned along 2 dimensions (the level of retail investor attention and institutional ownership), while controlling for firm size.

As before, we control for firm size by initially sorting all firms into terciles based on the firm's mean market capitalization over the previous 20 days. Then, within each size tercile, we form 3 finer portfolios by independently sorting based on i) the percentage of institutional ownership at the end of the previous quarter (INST) or ii) each proxy for retail attention yesterday $\left(\mathrm{VOL}_{t-1}\right.$ or RETAIL_ NETBUY $_{t-1}$ ). This procedure results in a $3 \times 3$ scheme of portfolios, sorted by size-adjusted institutional ownership and each proxy for retail attention.

Results are provided in Table 3. Panel A analyzes the main sample and uses yesterday's squared return $\left(\mathrm{VOL}_{t-1}\right)$ to proxy for retail investor attention at the open. This panel presents three $3 \times 3$ schemes of double-sorted portfolios that provide the mean overnight returns, trading day returns, and 24-hour returns, respectively. On average, there are 261 stocks in each of the 9 portfolios within every double-sorted partitioning scheme in Panel A.

First, consider the mean overnight returns (CTO) from the left $3 \times 3$ scheme in Panel A of Table 3. All portfolios in this scheme have positive mean overnight

\section{TABLE 3}

Overnight Returns, Trading Day Returns, and 24-Hour Returns across Portfolios Double-Sorted by Proxies for Retail Investor Attention Yesterday and Institutional Ownership

Table 3 reports mean overnight returns (close-to-open (CTO)), trading day returns (open-to-close (OTC)), and 24-hour returns (close-to-close $(\mathrm{CTC})$ ) for a $3 \times 3$ scheme of portfolios partitioned each day into terciles along 2 dimensions. The portfolios in each row are sorted according to a low, medium, or high level of retail investor attention yesterday; the columns are sorted by institutional ownership in the previous quarter. In Panel A we proxy retail investor attention using stock return volatility lagged 1 day. In Panel B we use the net number of shares bought by retail investors all day yesterday, as a percent of total share volume. For every portfolio in each $3 \times 3$ scheme, we first compute the mean return across firms every day, and we then average these cross-sectional means across all days in the sample period. * and ${ }^{* *}$ indicate statistical significance at the $5 \%$ and $1 \%$ levels, respectively. ${ }^{a}$ On average, there are 261 firms in the portfolio for each cell of these $3 \times 3$ partitioning schemes. ${ }^{b}$ On average, there are 90 firms in the portfolio for each cell of these $3 \times 3$ partitioning schemes.

Panel A. Using Stock Return Volatility Yesterday to Proxy for Retail Investor Attention: 3,000 Largest U.S. Stocks (1996-2008)

\begin{tabular}{|c|c|c|c|c|c|c|c|c|c|}
\hline Retail Investor Attention & \multicolumn{3}{|c|}{ Overnight Return (CTO\%) } & \multicolumn{3}{|c|}{ Trading Day Return (OTC\%) } & \multicolumn{3}{|c|}{ 24-Hour Return (CTC\%) } \\
\hline Stock Return Volatility & \multicolumn{3}{|c|}{ Institutional Ownership } & \multicolumn{3}{|c|}{ Institutional Ownership } & \multicolumn{3}{|c|}{ Institutional Ownership } \\
\hline Yesterday & Low & Medium & High & Low & Medium & High & Low & Medium & High \\
\hline Low & $0.03^{\star \star}$ & $0.02^{\star \star}$ & $0.02^{* \star}$ & $-0.03^{\star}$ & -0.03 & -0.03 & 0.00 & 0.00 & 0.00 \\
\hline Medium & $0.05^{\star \star}$ & $0.04^{* *}$ & $0.04^{\star \star}$ & $-0.06^{\star \star}$ & -0.04 & -0.04 & -0.01 & 0.01 & 0.00 \\
\hline High & $0.17^{\star \star}$ & $0.13^{\star \star}$ & $0.10^{\star \star}$ & $-0.17^{\star \star}$ & $-0.12^{\star \star}$ & $-0.09^{\star \star}$ & 0.00 & 0.01 & 0.01 \\
\hline High - Low & 0.13 & 0.11 & 0.08 & -0.13 & -0.09 & -0.07 & 0.00 & 0.02 & 0.01 \\
\hline t-statistic & $8.9^{* *}$ & $7.7^{\star \star}$ & $5.8^{\star \star}$ & $-4.0^{* \star}$ & $-2.7^{\star \star}$ & $-2.0^{*}$ & 0.0 & 0.4 & 0.3 \\
\hline \multicolumn{10}{|c|}{ Panel B. Using Net Retail Buying Yesterday to Proxy for Retail Investor Attention: NASDAQ Stocks (1997-2001) b } \\
\hline$\underline{\text { Retail Investor Attention }}$ & \multicolumn{3}{|c|}{ Overnight Return (CTO\%) } & \multicolumn{3}{|c|}{ Trading Day Return (OTC\%) } & \multicolumn{3}{|c|}{ 24-Hour Return (СTC\%) } \\
\hline Net Retail Buying & \multicolumn{3}{|c|}{ Institutional Ownership } & \multicolumn{3}{|c|}{ Institutional Ownership } & \multicolumn{3}{|c|}{ Institutional Ownership } \\
\hline Yesterday & Low & Medium & High & Low & Medium & High & Low & Medium & High \\
\hline Low & $0.09^{\star \star}$ & $0.06^{\star}$ & 0.02 & $-0.19^{\star \star}$ & $-0.15^{\star \star}$ & -0.09 & -0.09 & -0.09 & -0.07 \\
\hline Medium & $0.23^{\star \star}$ & $0.18^{\star *}$ & $0.13^{\star \star}$ & $-0.28^{\star \star}$ & $-0.21^{\star \star}$ & -0.10 & -0.06 & -0.03 & 0.02 \\
\hline High & $0.34^{\star \star}$ & $0.31^{\star *}$ & $0.24^{* \star}$ & $-0.42^{\star *}$ & $-0.30^{\star \star}$ & $-0.22^{\star \star}$ & -0.08 & 0.01 & 0.02 \\
\hline High - Low & 0.24 & 0.25 & 0.22 & -0.23 & -0.15 & -0.13 & 0.01 & 0.10 & 0.09 \\
\hline t-statistic & $6.4^{* *}$ & $7.1^{\star \star}$ & $6.5^{\star \star}$ & $-2.9^{* \star}$ & $-2.0^{\star}$ & -1.7 & 0.1 & 1.1 & 1.0 \\
\hline
\end{tabular}


returns, whose magnitudes increase with the level of retail investor attention. The bottom row of portfolios contains the largest means in this scheme, indicating that stocks with high retail attention tend to have the largest overnight returns. The mean difference $t$-test at the bottom of every column indicates that stocks with high retail attention significantly outperform stocks with low retail attention during the overnight period, conditional on institutional ownership. In addition, the left column of each scheme contains the largest element in every row, indicating that stocks with low institutional ownership tend to have the largest overnight returns. Finally, the bottom left corner cell contains stocks that are most prone to overpricing at the open, as they are subject to both high retail attention and low institutional ownership. The stocks in this cell have the largest mean overnight return, which averages +17 bp per day. In contrast, the top right corner cell contains stocks that are least prone to overpricing at the open, with low retail attention and high institutional ownership. The stocks in this cell have the smallest mean overnight return, at only +2 bp per day.

Second, consider the trading day returns (OTC) from the middle $3 \times 3$ scheme in Panel A of Table 3. All portfolios in this scheme have negative mean trading day reversals, whose magnitudes increase with the level of retail attention. However, these mean trading day reversals are only significant for portfolios in the bottom row, among stocks with high attention, or in the left column, among stocks with low institutional ownership. Here the mean difference $t$-test for every column shows that stocks with high retail attention significantly underperform stocks with low attention during the trading day. In addition, the bottom left corner cell now contains the largest negative mean trading day reversal in the scheme, at $-17 \mathrm{bp}$ per day, while the top right corner cell contains the smallest negative trading day reversal, at only -3 bp per day.

Third, the last $3 \times 3$ scheme in Panel A of Table 3 reinforces the result from the last column of Table 2, showing that attention-based overpricing at the open is a short-term intraday phenomenon. Even for the most overpriced stocks (subject to high retail attention and low institutional holdings), the significant price inflation at the open is completely reversed during the trading day, so that the mean close-to-close return is not significantly different from 0 .

Next consider the results in Panel B of Table 3, which analyze the abridged sample of NASDAQ stocks during 1997-2001 and use net retail buying yesterday to proxy for attention. These results are consistent with those in Panel A, although the price inflation at the open is substantially larger in magnitude for the abridged sample. In the first $3 \times 3$ scheme of Panel B, the mean overnight return for stocks most prone to overpricing at the open (i.e., the bottom left corner cell) is now +34 bp per day. This result contrasts with the top right corner cell, which contains the smallest mean overnight return, at only 2 bp per day. Similarly, in the second $3 \times 3$ scheme of Panel B, the mean trading day reversal for the bottom left corner cell is $-42 \mathrm{bp}$, but it is only $-9 \mathrm{bp}$ for the top right corner cell. Once again, the third $3 \times 3$ scheme of Panel B contains mean 24-hour returns that are smaller in magnitude and never significantly different from 0 .

One likely reason for the stronger intraday price pattern for the abridged sample of NASDAQ stocks during 1997-2001, in Panel B of Table 3, is that this period represents a time of high investor sentiment (e.g., see Baker and Wurgler 
(2006) and Section V). Furthermore, NASDAQ stocks as a group tend to have lower institutional ownership and are generally more volatile, more difficult to value, and more costly to arbitrage. We investigate these issues next.

\section{Stocks that Are Difficult to Value and Costly to Arbitrage}

This section further addresses our 2nd hypothesis by examining the relation between overpricing at the open and variables that proxy for the difficulty in valuing a stock, and the costs of arbitrage. Both of these attributes of a stock are likely to exacerbate the extent of overpricing at the open found in Table 3 (see Baker and Wurgler (2006), Kumar and Lee (2006)). To this end, Table 4 reproduces the analysis in each panel of Table 3, after restricting the samples used in Table 3 to focus on finer subsamples of stocks each day that are harder to value and more costly to arbitrage: i) We limit the sample to the $50 \%$ of firms each day with the highest return volatility over the previous 20 trading days, to represent stocks that are hard to value ${ }^{20}$ ii) we narrow this focus by considering the $50 \%$ of the hardto-value firms in i) with the highest mean effective half spread over the previous 20 trading days $;^{21}$ and iii) we further confine the sample each day to the $20 \%$ of the hard-to-value, high-transaction-cost firms in ii) with the highest relative short interest during the previous month. ${ }^{22}$

Panel A of Table 4 presents the results after applying all 3 restrictions above on the main sample, using volatility yesterday $\left(\mathrm{VOL}_{t-1}\right)$ to proxy for retail investor attention. Panel B presents the analogous results for the abridged sample, using net retail buying yesterday (RETAIL_NETBUY ${ }_{t-1}$ ) to proxy for attention.

First consider the results in Panel A of Table 4. After applying restrictions i)-iii) on the main sample, there are an average of 13 stocks within every doublesorted portfolio each day. The resulting $3 \times 3$ schemes in Panel A follow the same pattern as those in Table 3, although the positive overnight returns and negative trading day reversals are much larger in magnitude, as predicted. In particular, the bottom left corner cell of the 1st (2nd) $3 \times 3$ scheme in Panel A now reveals a mean overnight return (trading day reversal) of $+43(-45) \mathrm{bp}$.

Second, Panel B of Table 4 presents the analogous results for the abridged sample of NASDAQ stocks over the period from 1997 to 2001. After applying restrictions i)-iii) on the abridged sample, there are now an average of 5 firms within every double-sorted portfolio each day. The resulting $3 \times 3$ schemes in Panel B follow the same pattern, although the positive overnight returns and negative trading day reversals are much larger. In particular, the bottom left corner cell of the

\footnotetext{
${ }^{20}$ Baker and Wurgler (2006) argue that recent volatility is a good proxy for the difficulty in valuing stocks. We have also used the firm's book-to-market $(\mathrm{B} / \mathrm{M})$ ratio from the previous quarter as an alternative measure of this aspect of a stock. Results are consistent with those using return volatility over the past month and are summarized in Table 5. We also note that stocks with high volatility are costly to sell short, due to potential margin calls. Thus, high volatility also represents a potential limit to arbitrage.

${ }^{21}$ Sadka and Scherbina (2007) propose that high transaction costs act as an additional limit to arbitrage, and they document that such stocks underperform over time.

${ }^{22}$ Asquith et al. (2005) argue that stocks with both low institutional ownership and high short interest are subject to more binding short sale constraints.
} 


\section{TABLE 4}

Overnight Returns, Trading Day Returns, and 24-Hour Returns across Double-Sorted Portfolios, for Subsamples of Stocks Each Day that Are Hard to Value, with High Transaction Costs, and with High Short Interest

\begin{tabular}{|c|c|c|c|c|c|c|c|c|c|}
\hline \multicolumn{10}{|c|}{$\begin{array}{l}\text { Table } 4 \text { follows the same forn } \\
\text { order to analyze the subsam } \\
\text { volatility over the past } 20 \text { da } \\
\text { spread), and iii) with high sho } \\
\text { analogous results using yest } \\
\text { the } 5 \% \text { and } 1 \% \text { levels, resper } \\
\text { schemes. }{ }^{b} \text { On average, ther } \\
\text { Panel A. Using Stock Return } \\
\text { U.S. Stocks (1996-2008) }\end{array}$} \\
\hline$\underline{\text { Retail Investor Attention }}$ & \multicolumn{3}{|c|}{ Overnight Return (CTO\%) } & \multicolumn{3}{|c|}{ Trading Day Return (OTC\%) } & \multicolumn{3}{|c|}{ 24-Hour Return (CTC\%) } \\
\hline Stock Return Volatility & \multicolumn{3}{|c|}{ Institutional Ownership } & \multicolumn{3}{|c|}{ Institutional Ownership } & \multicolumn{3}{|c|}{ Institutional Ownership } \\
\hline Yesterday & Low & Medium & High & Low & Medium & High & Low & Medium & High \\
\hline $\begin{array}{l}\text { Low } \\
\text { Medium } \\
\text { High }\end{array}$ & $\begin{array}{l}0.15^{\star \star} \\
0.22^{\star \star} \\
0.43^{\star \star}\end{array}$ & $\begin{array}{l}0.07 \\
0.19^{\star *} \\
0.39^{\star *}\end{array}$ & $\begin{array}{l}0.12^{\star \star} \\
0.14^{\star \star} \\
0.29^{\star \star}\end{array}$ & $\begin{array}{l}-0.33^{\star \star} \\
-0.35^{\star \star} \\
-0.45^{\star \star}\end{array}$ & $\begin{array}{l}-0.27^{\star \star} \\
-0.24^{\star \star} \\
-0.35^{\star \star}\end{array}$ & $\begin{array}{l}-0.18^{* \star} \\
-0.19^{* \star} \\
-0.30^{* \star}\end{array}$ & $\begin{array}{l}-0.19^{\star \star} \\
-0.13^{\star \star} \\
-0.02\end{array}$ & $\begin{array}{l}-0.20^{* *} \\
-0.06 \\
0.04\end{array}$ & $\begin{array}{l}-0.07 \\
-0.05 \\
-0.01\end{array}$ \\
\hline $\begin{array}{l}\text { High - Low } \\
t \text {-statistic }\end{array}$ & $\begin{array}{l}0.28 \\
8.6^{\star \star}\end{array}$ & $\begin{array}{l}0.32 \\
6.4^{\star \star}\end{array}$ & $\begin{array}{l}0.18 \\
6.0^{* *}\end{array}$ & $\begin{array}{l}-0.12 \\
-1.8\end{array}$ & $\begin{array}{l}-0.08 \\
-1.1\end{array}$ & $\begin{array}{l}-0.12 \\
-1.8\end{array}$ & $\begin{array}{l}0.16 \\
2.2^{*}\end{array}$ & $\begin{array}{l}0.24 \\
2.7^{\star \star}\end{array}$ & $\begin{array}{l}0.06 \\
0.8\end{array}$ \\
\hline \multicolumn{10}{|c|}{ Panel B. Using Net Retail Buying Yesterday to Proxy for Retail Investor Attention: NASDAQ Stocks (1997-2001) } \\
\hline$\underline{\text { Retail Investor Attention }}$ & \multicolumn{3}{|c|}{ Overnight Return (СТO\%) } & \multicolumn{3}{|c|}{ Trading Day Return (OTC\%) } & \multicolumn{3}{|c|}{ 24-Hour Return (CTC\%) } \\
\hline Net Retail Buying & \multicolumn{3}{|c|}{ Institutional Ownership } & \multicolumn{3}{|c|}{ Institutional Ownership } & \multicolumn{3}{|c|}{ Institutional Ownership } \\
\hline Yesterday & Low & $\underline{\text { Medium }}$ & $\underline{\text { High }}$ & Low & Medium & High & Low & $\underline{\text { Medium }}$ & High \\
\hline $\begin{array}{l}\text { Low } \\
\text { Medium } \\
\text { High }\end{array}$ & $\begin{array}{l}0.35^{\star \star} \\
0.47^{\star \star} \\
0.61^{\star \star}\end{array}$ & $\begin{array}{l}0.27^{\star *} \\
0.46^{\star *} \\
0.65^{\star *}\end{array}$ & $\begin{array}{l}0.10 \\
0.27^{\star \star} \\
0.49^{\star \star}\end{array}$ & $\begin{array}{l}-0.43^{\star \star} \\
-0.71^{\star \star} \\
-0.70^{\star \star}\end{array}$ & $\begin{array}{l}-0.47^{\star \star} \\
-0.61^{\star \star} \\
-0.67^{\star \star}\end{array}$ & $\begin{array}{l}-0.24^{\star} \\
-0.43^{\star \star} \\
-0.52^{\star \star}\end{array}$ & $\begin{array}{l}-0.08 \\
-0.24 \\
-0.09\end{array}$ & $\begin{array}{l}-0.20 \\
-0.15 \\
-0.02\end{array}$ & $\begin{array}{l}-0.14 \\
-0.15 \\
-0.03\end{array}$ \\
\hline $\begin{array}{l}\text { High - Low } \\
t \text {-statistic }\end{array}$ & $\begin{array}{l}0.26 \\
3.3^{\star \star}\end{array}$ & $\begin{array}{l}0.38 \\
4.8^{\star \star}\end{array}$ & $\begin{array}{l}0.39 \\
5.0^{* *}\end{array}$ & $\begin{array}{l}-0.27 \\
-1.8\end{array}$ & $\begin{array}{l}-0.20 \\
-1.2\end{array}$ & $\begin{array}{l}-0.28 \\
-1.9\end{array}$ & $\begin{array}{l}-0.01 \\
-0.1\end{array}$ & $\begin{array}{l}0.18 \\
1.0\end{array}$ & $\begin{array}{l}0.11 \\
0.7\end{array}$ \\
\hline
\end{tabular}

1st (2nd) $3 \times 3$ scheme in Panel B now reveals a mean overnight return (trading day reversal) of $+61(-70)$ bp per day.

Together, the results in Table 4 reinforce the view that high-attention firms have positive overnight returns and trading day reversals that are larger in magnitude when the firm is more difficult to value, transaction costs are higher, and short sale constraints are more binding. This evidence provides further support for our theory of attention-based overpricing at the open. ${ }^{23}$

\section{Variation over Time in Overpricing at the Open: The Role of Sentiment}

The previous sections establish that, for a large group of stocks subject to high attention and low institutional holdings, the opening price tends to be very high relative to intraday prices. In this section we examine how the magnitude

\footnotetext{
${ }^{23}$ In tests not reported here, we have reproduced this analysis for each stage of this progression to finer subsamples of stocks that are more difficult to value and more costly to arbitrage, after applying each restriction, i)-iii), in turn. At each stage, the $3 \times 3$ schemes reveal progressively larger overnight returns and trading day reversals. Results are available from the authors.
} 
of this opening price inflation changes through time, and whether any such time variation in this overpricing is related to changes in investor sentiment.

This analysis requires a time-series measure that tracks the level of retail investor sentiment over time. We examine 2 alternative proxies. Our 1st measure is the sentiment index in Baker and Wurgler (2006), (2007). This sentiment measure is a composite index based on the 1st principal component of 6 sentiment proxies, orthogonalized with respect to several macroeconomic conditions. The BakerWurgler (2006) sentiment index is available on a monthly basis from the start of our sample period to the end of $2007 .^{24}$

Our 2nd measure is the actual net buying activity of retail investors during the 1st hour of the trading day, as a percent of shares outstanding, averaged across all stocks and days during the month. This measure is motivated by the results in Table 2, which indicate that net retail buying near the day's open is an effective proxy for cross-sectional differences in retail investor sentiment based on attention. We refer to this measure as our retail sentiment index. The available data on net retail buying enable measurement of this sentiment index on a monthly basis for the abridged sample of NASDAQ stocks over the period from 1997 to 2001.

Our tests in this section are designed to establish whether monthly variation in these 2 proxies for retail investor sentiment can explain variation through time in the extent to which opening prices are pushed above "fundamental" values (i.e., values during the rest of the trading day). In order to measure the extent of opening price inflation during a given month, we first calculate daily overnight and trading day returns for groups of stocks classified using the same procedures as before. That is, for each day we compute the mean overnight and trading day returns for the $3 \times 3$ scheme of portfolios sorted along 2 dimensions: sizeadjusted institutional ownership and retail investor attention yesterday. Next, for each month, we calculate the mean daily overnight and trading day returns to measure the average daily performance of each portfolio during the overnight and trading day periods, respectively, throughout that month. Thus, our monthly overnight (trading day) return measure for each portfolio, $\mathrm{CTO}_{m}\left(\mathrm{OTC}_{m}\right)$, contains the mean of daily overnight (trading day) returns during each month $(m)$.

We then examine the monthly performance of a zero-cost hedge portfolio that is long the stocks that are most subject to inflation of opening prices (i.e., the bottom left corner portfolio in the $3 \times 3$ scheme) and short the stocks that are least subject to inflation of opening prices (i.e., the top right corner portfolio). That is, each day this hedge portfolio is long stocks with low institutional holdings and high attention (bottom left corner), and short stocks with high institutional ownership and low attention (top right corner). The monthly mean trading day (open-to-close) return on this hedge portfolio represents the extent to which the opening price exceeds the close, for stocks most prone to opening price inflation relative to stocks least prone to this overpricing. Likewise, this monthly average trading day return on the hedge portfolio provides one measure of changes over time in market-wide hidden costs associated with the tendency for retail investors to buy attention-grabbing stocks at the open (rather than the close).

\footnotetext{
${ }^{24}$ For details, see Baker and Wurgler (2006). Their monthly sentiment index can be downloaded from Jeffrey Wurgler's Web site (www.stern.nyu.edu/ jwurgler).
} 
Figure 2 plots the evolution over the period from 1996 to 2009, of several variables that measure retail investor sentiment, the extent of overpricing at the open, and transaction costs. First, we plot in Figure 2 movements in the BakerWurgler (2006) sentiment index over this period. Second, we also plot the average return on the hedge portfolio during the overnight and trading day periods, respectively, using yesterday's return squared as the attention proxy. Finally, we plot the daily average (negative value of the) effective half spread for the subsample of stocks most sensitive to price inflation at the open (i.e., stocks with low institutional ownership and high attention). ${ }^{25}$

\title{
FIGURE 2
}

Retail Investor Sentiment, Overnight Returns, and Transaction Costs (1996-2009)

\begin{abstract}
Figure 2 presents the evolution over the period from 1996 to 2009, of several variables that measure retail investor sentiment, the extent of overpricing at the open, and transaction costs. First, we report quarterly averages of the monthly "BakerWurgler (2006) Sentiment Index." Next, for each quarter, "Overnight Returns" plots the average daily overnight (close-toopen) return of a zero-cost hedge portfolio that is long stocks with low institutional holdings and high attention (i.e., the bottom left corner of the $3 \times 3$ scheme in Table 3 ), and short stocks with high institutional ownership and low attention (i.e., top right corner of the scheme). "Trading Day Returns" plots the average trading day (open-to-close) return on the same hedge portfolio. We also plot the average daily "Effective Half Spread" for the subsample of stocks that are most sensitive to price inflation at the open (i.e., stocks in the bottom left corner of the scheme, with high attention and low institutional ownership). Returns and spread are in percentage points.
\end{abstract}

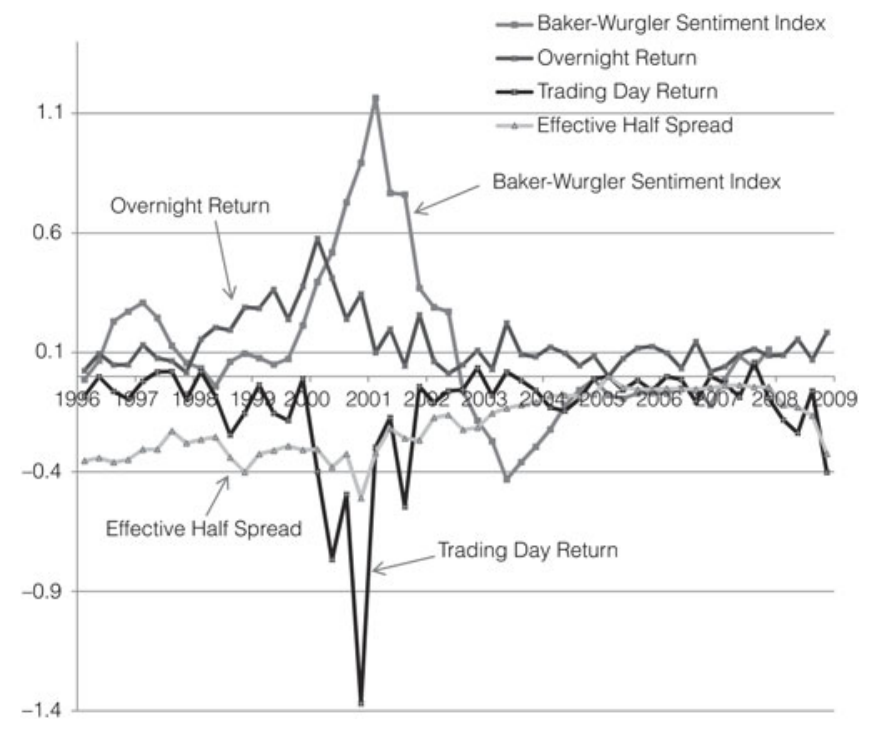

Figure 3 presents the analogous information using our retail sentiment index, for the abridged sample of NASDAQ stocks over the period from 1997 to 2001. In this figure we compile the returns on the hedge portfolio using yesterday's net retail buying as our proxy for attention. For comparison, we also plot the Baker-Wurgler (2006) sentiment index and the (negative value of the)

\footnotetext{
${ }^{25}$ For clarity, we divide the Baker-Wurgler (2006) sentiment index by 2 and report quarterly averages of all variables.
} 


\section{FIGURE 3}

Retail Investor Sentiment, Overnight Returns, and Transaction Costs (1997-2002)

Figure 3 presents the evolution over the period from 1997 to 2002, of several variables that measure retail investor sentiment, the extent of overpricing at the open, and transaction costs. We report quarterly averages of the monthly "Baker-Wurgle (2006) Sentiment Index" and the quarterly average of the "Retail Investor Sentiment Index" (defined as the actual net buying activity by retail investors during the 1st hour of the trading day, as a percent of shares outstanding, averaged across all stocks and all days during the quarter). For each quarter, "Overnight Return" plots the average daily overnight (close-to-open) return of a zero-cost hedge portfolio that is long stocks with low institutional holdings and high attention (i.e., bottom left corner of the $3 \times 3$ scheme in Table 3 ), and short stocks with high institutional ownership and low attention (i.e., top right corner of the scheme). "Trading Day Return" plots the average trading day (open-to-close) return on the same hedge portfolio. We also plot the average daily "Effective Half Spread" for the subsample of stocks that are most sensitive to price inflation at the open (i.e., stocks in the bottom left corner of the scheme, with high attention and low institutional ownership). Returns and spread are in percentage points.

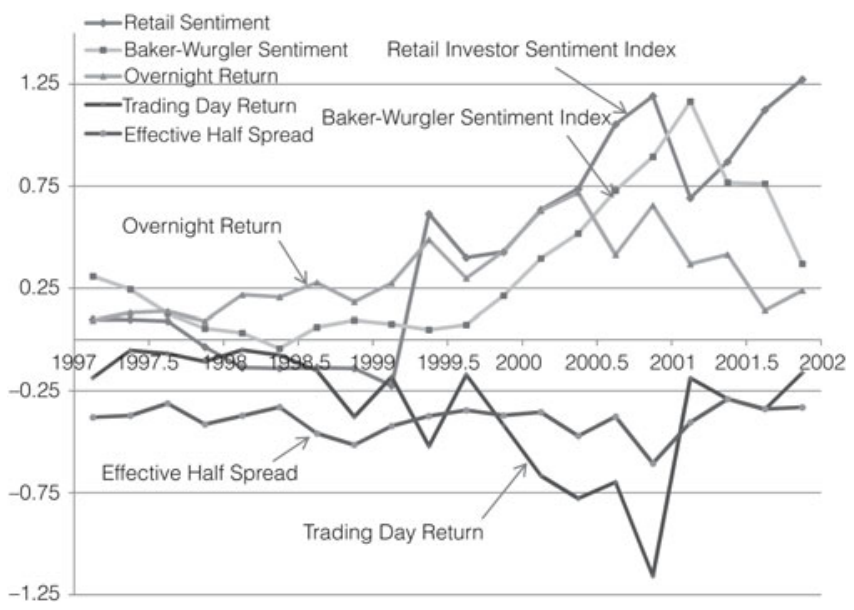

mean effective half spread for the portfolio of stocks most subject to opening price inflation. ${ }^{26}$

First consider the information in Figure 2. This plot reveals that overnight returns on the hedge portfolio are positively related to the Baker-Wurgler (2006) sentiment index (correlation is $0.30, p$-value is 0.001 ), while trading day returns are negatively related to this index (correlation is $-0.33, p$-value is 0.001 ). Similarly, we find that the retail sentiment index in Figure 3 has a correlation of 0.47 ( $p$-value is 0.001 ) with overnight returns on the hedge portfolio, and a correlation of -0.51 ( $p$-value is 0.001 ) with trading day returns on the hedge portfolio. Furthermore, in Figure 3 the Baker-Wurgler (2006) index is highly correlated with the retail sentiment index. Based on the 60 months for which we have data on both indices, we find a correlation of 0.77 ( $p$-value is 0.001 ).

It is noteworthy that the positive overnight returns on the hedge portfolio in Figures 2 and 3 become very large just prior to the technology crash in March of 2000 and remain positive throughout 2001. In comparison, the negative trading day reversals on the hedge portfolio become even larger as this crash develops.

\footnotetext{
${ }^{26}$ Here we divide the Baker-Wurgler (2006) sentiment index by 2, multiply the retail sentiment index by 10 , and report quarterly averages of the variables.
} 
Apparently, the bulk of the 2000 correction in stocks most subject to opening price inflation occurred during the trading day. ${ }^{27}$

Figures 2 and 3 also plot the average effective half spread for the subsample of stocks most prone to price inflation at the open (i.e., those subject to high attention and low institutional ownership). For comparison purposes, the negative value of this measure of transaction costs is plotted alongside the trading day (open-to-close) return of the hedge portfolio. Once again, we regard this trading day return on the hedge portfolio as a measure of the implicit cost of buying at the open (rather than the close) those stocks most prone to opening price inflation. Both Figures 2 and 3 show that this implicit cost of buying at the open is similar in magnitude to the effective half spread for much of the sample period. Moreover, in times of high investor sentiment, this mean trading day reversal can be more than twice the size of the effective half spread.

The major practical implication of this analysis is that retail traders incur a substantial hidden transaction cost when they buy attention-grabbing stocks at the open of the next trading day, because their herding behavior results in inflated opening prices. The plots reveal that, over long periods, this implicit transaction cost is similar in magnitude to the effective half spread.

\section{Robustness Tests}

\section{A. Alternative Portfolio Approaches}

In Panel A of Table 5, we apply the main analysis from our portfolio approach of Table 3, but we base this analysis on alternative return measures, various subsamples of stocks, or different time periods. For each test, the 4 columns on the left side of Table 5 report results based on the main sample of the 3,000 largest U.S. stocks over the period from 1996 to 2008, where the level of retail investor attention is proxied by return volatility yesterday $\left(\mathrm{VOL}_{t-1}\right)$. The right 4 columns present the analogous results based on the abridged sample of NASDAQ stocks over the period from 1997 to 2001, using retail net buying yesterday (RETAIL_NETBUY ${ }_{t-1}$ ) to proxy for attention.

For brevity, in all of these robustness tests we only present the mean returns for the 2 extreme corner portfolios of every $3 \times 3$ scheme, for stocks with low institutional holdings and high attention (bottom left corner) and for stocks with high institutional holdings and low attention (top right corner). The base case provided at the top of Table 5 reproduces the results for these 2 corner portfolios from Table 3. In every subsequent robustness test (row) of Panel A, we change only one aspect of the analysis to facilitate comparison with the base case.

The series of tests in Panel A of Table 5 reveals that our results are robust when we use market-adjusted returns, median returns, or trade prices to

\footnotetext{
${ }^{27}$ We also note that the Baker-Wurgler (2006) sentiment index in Figures 2 and 3 peaks a few months after March 2000, and after the peak of our retail investor sentiment index in Figure 3. This delay in the peak of the Baker-Wurgler (2006) index may be due to their use of a 12-month lag for 3 of the 6 components in their index. They argue that combining these lagged values for 3 of their series with current values of the other 3 series best captures annual variation in the 6 series (see Baker and Wurgler (2006), (2007)).
} 
TABLE 5

\section{Robustness Tests: Alternative Portfolio Approaches and Regression Analysis}

For every robustness test in Panel A of Table 5, we reproduce the portfolio approach from Table 3, but we change some aspect of the analysis. For brevity, we present only the 2 cells in each $3 \times 3$ scheme that are subject to the greatest and least forces behind overpricing at the open: the bottom left corner cell and the top right corner cell. The base case reproduces these 2 corner cells from the $3 \times 3$ schemes in Table 3 . In each subsequent test (row) of Panel A, we change only one aspect of the analysis to facilitate comparison with the base case. Panel B provides the results of Fama-MacBeth (1973) regression analysis. First, for each day in the sample period we estimate the cross-sectional regression model in equation (1) for overnight returns (CTO) or for trading day returns (OTC). Second, we compute the time-series mean coefficients across all days in the sample period. * and ${ }^{* *}$ indicate statistical significance at the $5 \%$ and $1 \%$ levels, respectively. ${ }^{\text {a }}$ Results based on trade prices using $\mathrm{VOL}_{t-1}$ are computed over the sample period $1996-2004 .{ }^{b}$ For the NASDAQ stocks in the right 4 columns, cutoffs of market capitalization for small and large stock quintiles are based on the stratification each day using the 3,000 largest U.S. stocks. ${ }^{C}$ For the NASDAQ stocks in the right 4 columns, cutoffs of book-to-market (B/M) for growth and value stock quintiles are based on the stratification each day using the 3,000 largest U.S. stocks. ${ }^{\mathrm{D}} \mathrm{Data}$ on RETAIL_NETBUY $t_{-1}$ are unavailable before 1997, so the entries in this row for this proxy are for 1997-2000. ${ }^{e}$ Data on RETAIL_NETBUY $t_{-1}$ are unavailable after 2001, so the entries in this row using this proxy are for 2001 only.

Panel A. Portfolio Approach: Alternative Return Measures and Subsamples

Bottom Left and Top Right Corner Cells in Each 3 × 3 Matrix

\begin{tabular}{c} 
Sample: \\
\hline Attention Proxy: \\
\hline Return Measure: \\
\hline
\end{tabular}

Cell in $3 \times 3$ Matrix:

\begin{tabular}{c} 
Base Case (Table 3) \\
Newey-West $t$-Ratio \\
\hline $\begin{array}{c}\text { 1. Using market-adjusted } \\
\text { abnormal returns }\end{array}$
\end{tabular}

2. Using trade prices ${ }^{a}$ to measure returns

3. Using median return across stocks each day

4. No low-price stocks

(with price <\$5)

5. NASDAQ stocks

6. NYSE stocks

7. Small stock quintile ${ }^{b}$

8. Large stock quintile ${ }^{b}$

9. Growth stocks (low quintile, B/M) $^{\mathrm{C}}$

10. Value stocks (high quintile, B/M) ${ }^{\mathrm{C}}$

11. Momentum losers (low quintile, 6-mo. return)

12. Momentum winners (high quintile, 6-mo. return)

13. Mondays

14. Other weekdays

15. $1996-2000^{d}$

16. $2001-2004^{e}$

17. 2005-2008

\begin{tabular}{|c|c|c|c|c|c|c|c|}
\hline 3,00 & est U & ocks (1 & 2008) & & AQ St & S (1997 & 01) \\
\hline & & & & & RETAIL & TBUY & \\
\hline & & OT & & & $(\%)$ & & (\%) \\
\hline $\begin{array}{l}\text { Bottom } \\
\text { Left }\end{array}$ & $\begin{array}{c}\text { Top } \\
\text { Right }\end{array}$ & $\begin{array}{c}\text { Bottom } \\
\text { Left }\end{array}$ & $\begin{array}{l}\text { Top } \\
\text { Right }\end{array}$ & $\begin{array}{l}\text { Bottom } \\
\text { Left }\end{array}$ & $\begin{array}{l}\text { Top } \\
\text { Right }\end{array}$ & $\begin{array}{c}\text { Bottom } \\
\text { Left }\end{array}$ & $\begin{array}{c}\text { Top } \\
\text { Right }\end{array}$ \\
\hline $\begin{array}{c}0.17 \\
11.9^{\star *}\end{array}$ & $\begin{array}{l}0.02 \\
3.5^{\star *}\end{array}$ & $\begin{array}{l}-0.17 \\
-5.6^{\star \star}\end{array}$ & $\begin{array}{l}-0.03 \\
-1.3\end{array}$ & $\begin{array}{c}0.34 \\
11.3^{\star \star}\end{array}$ & $\begin{array}{l}0.02 \\
1.0\end{array}$ & $\begin{array}{l}-0.42 \\
-6.8^{\star \star}\end{array}$ & $\begin{array}{l}-0.09 \\
-1.8\end{array}$ \\
\hline $\begin{array}{c}0.12 \\
14.1^{\star \star}\end{array}$ & $\begin{array}{l}-0.03 \\
-4.2^{* *}\end{array}$ & $\begin{array}{r}-0.18 \\
-10.1^{\star \star}\end{array}$ & $\begin{array}{l}-0.03 \\
-3.5^{\star \star}\end{array}$ & $\begin{array}{c}0.24 \\
12.3^{\star \star}\end{array}$ & $\begin{array}{l}-0.07 \\
-5.6^{\star \star}\end{array}$ & $\begin{array}{l}-0.42 \\
-9.8^{\star \star}\end{array}$ & $\begin{array}{l}-0.09 \\
-3.0\end{array}$ \\
\hline $\begin{array}{c}0.17 \\
10.1^{\text {** }}\end{array}$ & 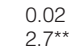 & $\begin{array}{l}-0.17 \\
-4.8^{\star \star}\end{array}$ & $\begin{array}{l}-0.01 \\
-0.3\end{array}$ & $\begin{array}{c}0.33 \\
11.0^{\text {** }}\end{array}$ & $\begin{array}{l}0.00 \\
0.2\end{array}$ & $\begin{array}{l}-0.41 \\
-6.8^{\text {*ᄎ }}\end{array}$ & $\begin{array}{l}-0.08 \\
-1.4\end{array}$ \\
\hline $\begin{array}{l}0.09 \\
9.2^{\star \star}\end{array}$ & $\begin{array}{l}0.02 \\
3.4^{\star \star}\end{array}$ & $\begin{array}{l}-0.16 \\
-6.5^{\star \star}\end{array}$ & $\begin{array}{l}-0.04 \\
-2.5^{\star}\end{array}$ & $\begin{array}{l}0.20 \\
9.5^{\text {*ᄎ }}\end{array}$ & $\begin{array}{l}0.01 \\
0.8\end{array}$ & $\begin{array}{l}-0.42 \\
-8.7^{\star \star}\end{array}$ & $\begin{array}{l}-0.11 \\
-2.5^{\star}\end{array}$ \\
\hline $\begin{array}{l}0.13 \\
9.4^{\star *}\end{array}$ & $\begin{array}{l}0.02 \\
2.9^{* *}\end{array}$ & $\begin{array}{l}-0.13 \\
-4.5^{\star \star}\end{array}$ & $\begin{array}{l}-0.02 \\
-1.1\end{array}$ & $\begin{array}{c}0.30 \\
10.0^{\star \star}\end{array}$ & $\begin{array}{l}0.02 \\
0.8\end{array}$ & $\begin{array}{l}-0.37 \\
-6.0^{\star \star}\end{array}$ & $\begin{array}{l}-0.09 \\
-1.7\end{array}$ \\
\hline $\begin{array}{c}0.28 \\
13.9^{* *}\end{array}$ & $\begin{array}{l}0.03 \\
3.6^{* \star}\end{array}$ & $\begin{array}{l}-0.27 \\
-7.1^{\star \star}\end{array}$ & $\begin{array}{l}-0.07 \\
-2.5^{\star}\end{array}$ & $\begin{array}{c}0.34 \\
11.3^{\star \star}\end{array}$ & $\begin{array}{l}0.02 \\
1.0\end{array}$ & $\begin{array}{l}-0.42 \\
-6.8^{\star \star}\end{array}$ & $\begin{array}{l}-0.09 \\
-1.8\end{array}$ \\
\hline $\begin{array}{l}0.09 \\
6.0^{\star \star}\end{array}$ & $\begin{array}{l}0.01 \\
0.8\end{array}$ & $\begin{array}{l}-0.07 \\
-3.1^{\star \star}\end{array}$ & $\begin{array}{l}-0.01 \\
-0.7\end{array}$ & - & - & - & - \\
\hline $\begin{array}{c}0.29 \\
18.3^{\text {** }}\end{array}$ & $\begin{array}{l}0.07 \\
8.6^{\star *}\end{array}$ & $\begin{array}{l}-0.19 \\
-5.3^{\star \star}\end{array}$ & $\begin{array}{l}-0.05 \\
-2.1^{\star}\end{array}$ & $\begin{array}{c}0.45 \\
13.8^{\text {** }}\end{array}$ & $\begin{array}{l}0.07 \\
3.3^{\star \star}\end{array}$ & $\begin{array}{l}-0.39 \\
-5.9^{\star \star}\end{array}$ & $\begin{array}{l}-0.08 \\
-1.4\end{array}$ \\
\hline $\begin{array}{l}0.09 \\
5.1^{\text {** }}\end{array}$ & $\begin{array}{l}0.01 \\
1.5\end{array}$ & $\begin{array}{l}-0.11 \\
-3.9^{\text {*ᄎ }}\end{array}$ & $\begin{array}{l}0.00 \\
0.2\end{array}$ & $\begin{array}{l}0.32 \\
6.8^{\star \star}\end{array}$ & $\begin{array}{l}0.07 \\
1.9\end{array}$ & $\begin{array}{l}-0.37 \\
-4.2^{\star \star}\end{array}$ & $\begin{array}{l}-0.21 \\
-2.9^{\star \star}\end{array}$ \\
\hline $\begin{array}{l}0.20 \\
9.8^{* *}\end{array}$ & $\begin{array}{l}0.03 \\
3.4^{* *}\end{array}$ & $\begin{array}{l}-0.23 \\
-6.0^{\star \star}\end{array}$ & $\begin{array}{l}-0.04 \\
-1.5\end{array}$ & $\begin{array}{l}0.37 \\
8.6^{\text {** }}\end{array}$ & $\begin{array}{l}0.04 \\
1.2\end{array}$ & $\begin{array}{l}-0.46 \\
-5.5^{\star \star}\end{array}$ & $\begin{array}{l}-0.14 \\
-1.9\end{array}$ \\
\hline $\begin{array}{l}0.13 \\
9.5^{\star *}\end{array}$ & $\begin{array}{l}0.04 \\
4.7^{\star *}\end{array}$ & $\begin{array}{l}-0.09 \\
-3.0^{\star \star}\end{array}$ & $\begin{array}{l}-0.03 \\
-1.5\end{array}$ & $\begin{array}{l}0.23 \\
6.2^{\text {** }}\end{array}$ & $\begin{array}{l}-0.01 \\
-0.3\end{array}$ & $\begin{array}{l}-0.24 \\
-3.5^{\star \star}\end{array}$ & $\begin{array}{l}-0.01 \\
-0.2\end{array}$ \\
\hline $\begin{array}{c}0.32 \\
14.7^{\star \star}\end{array}$ & $\begin{array}{l}0.06 \\
6.2^{\star \star}\end{array}$ & $\begin{array}{l}-0.31 \\
-8.0^{\star \star}\end{array}$ & $\begin{array}{l}-0.08 \\
-3.0^{\star \star}\end{array}$ & $\begin{array}{c}0.48 \\
12.5^{\star \star}\end{array}$ & $\begin{array}{l}0.09 \\
3.2^{\star \star}\end{array}$ & $\begin{array}{l}-0.61 \\
-7.9^{\star \star}\end{array}$ & $\begin{array}{l}-0.17 \\
-2.7^{\star \star}\end{array}$ \\
\hline $\begin{array}{l}0.14 \\
9.0^{\star \star}\end{array}$ & $\begin{array}{l}0.03 \\
3.4^{\star \star}\end{array}$ & $\begin{array}{l}-0.13 \\
-4.0^{\star \star}\end{array}$ & $\begin{array}{l}-0.04 \\
-1.7\end{array}$ & $\begin{array}{l}0.26 \\
8.5^{\text {*ᄎ }}\end{array}$ & $\begin{array}{l}0.02 \\
1.3\end{array}$ & $\begin{array}{l}-0.25 \\
-3.8^{\star \star}\end{array}$ & $\begin{array}{l}-0.12 \\
-1.9\end{array}$ \\
\hline $\begin{array}{l}0.20 \\
5.8^{* *}\end{array}$ & $\begin{array}{l}0.04 \\
3.0^{\star *}\end{array}$ & $\begin{array}{l}-0.35 \\
-5.4^{\star \star}\end{array}$ & $\begin{array}{l}-0.11 \\
-2.6^{\star \star}\end{array}$ & $\begin{array}{l}0.37 \\
5.4^{\star \star}\end{array}$ & $\begin{array}{l}0.05 \\
1.0\end{array}$ & $\begin{array}{l}-0.66 \\
-4.8^{\star \star}\end{array}$ & $\begin{array}{l}-0.30 \\
-2.7^{\star \star}\end{array}$ \\
\hline $\begin{array}{c}0.16 \\
10.3^{\text {** }}\end{array}$ & $\begin{array}{l}0.02 \\
2.5^{\star}\end{array}$ & $\begin{array}{l}-0.12 \\
-3.8^{\star \star}\end{array}$ & $\begin{array}{l}-0.01 \\
-0.2\end{array}$ & $\begin{array}{l}0.33 \\
9.9^{\star \star}\end{array}$ & $\begin{array}{l}0.02 \\
0.7\end{array}$ & $\begin{array}{l}-0.36 \\
-5.6^{\star \star}\end{array}$ & $\begin{array}{l}-0.04 \\
-0.8\end{array}$ \\
\hline $\begin{array}{c}0.25 \\
10.2^{* *}\end{array}$ & $\begin{array}{l}0.04 \\
4.1^{\star *}\end{array}$ & $\begin{array}{l}-0.24 \\
-5.0^{\star \star}\end{array}$ & $\begin{array}{l}-0.03 \\
-1.4\end{array}$ & $\begin{array}{c}0.37 \\
11.4^{\star \star}\end{array}$ & $\begin{array}{l}0.05 \\
2.2^{*}\end{array}$ & $\begin{array}{l}-0.46 \\
-6.9^{\star \star}\end{array}$ & $\begin{array}{l}-0.12 \\
-2.2^{\star}\end{array}$ \\
\hline $\begin{array}{l}0.16 \\
6.4^{\text {** }}\end{array}$ & $\begin{array}{l}0.00 \\
0.3\end{array}$ & $\begin{array}{l}-0.22 \\
-4.1^{\star \star}\end{array}$ & $\begin{array}{l}0.01 \\
0.5\end{array}$ & $\begin{array}{l}0.17 \\
2.5^{\star}\end{array}$ & $\begin{array}{l}-0.11 \\
-2.2^{\star}\end{array}$ & $\begin{array}{l}-0.21 \\
-1.4\end{array}$ & $\begin{array}{l}0.03 \\
0.3\end{array}$ \\
\hline $\begin{array}{l}0.13 \\
5.2^{* *}\end{array}$ & $\begin{array}{l}0.03 \\
2.0^{*}\end{array}$ & $\begin{array}{l}-0.16 \\
-2.7^{\star \star}\end{array}$ & $\begin{array}{l}-0.07 \\
-1.5\end{array}$ & - & - & - & - \\
\hline
\end{tabular}

(continued on next page) 
TABLE 5 (continued)

Robustness Tests: Alternative Portfolio Approaches and Regression Analysis

\begin{tabular}{|c|c|c|c|c|}
\hline \multicolumn{5}{|c|}{ Panel B. Fama-MacBeth Regression Analysis of Model (1) } \\
\hline Sample: & \multicolumn{2}{|c|}{ 3,000 Largest U.S. Stocks (1996-2008) } & \multicolumn{2}{|c|}{ NASDAQ Stocks (1997-2001) } \\
\hline Attention Proxy: & \multicolumn{2}{|c|}{$\mathrm{VOL}_{t-1}$} & \multicolumn{2}{|c|}{ RETAIL_NETBUY $Y_{t-1}$} \\
\hline Dependent Variable: & $\underline{\mathrm{CTO}(\%)}$ & $\underline{\text { OTC(\%) }}$ & $\underline{\mathrm{CTO}(\%)}$ & OTC(\%) \\
\hline Attention & $\begin{array}{l}0.179 \\
4.8^{\star \star}\end{array}$ & $\begin{array}{l}-0.272 \\
-9.0^{\star *}\end{array}$ & $\begin{array}{c}0.218 \\
15.5^{\star \star}\end{array}$ & $\begin{array}{l}-0.178 \\
-6.0^{\star \star}\end{array}$ \\
\hline Institutional ownership & $\begin{array}{l}-0.035 \\
-2.5^{\star}\end{array}$ & $\begin{array}{l}0.093 \\
4.4^{* *}\end{array}$ & $\begin{array}{l}-0.113 \\
-4.0^{\star *}\end{array}$ & $\begin{array}{l}0.335 \\
3.8^{* *}\end{array}$ \\
\hline Firm size & $\begin{array}{l}0.024 \\
0.7\end{array}$ & $\begin{array}{c}0.159 \\
11.9^{* \star}\end{array}$ & $\begin{array}{l}0.010 \\
0.3\end{array}$ & $\begin{array}{l}0.309 \\
8.5^{\star \star}\end{array}$ \\
\hline Avg. no. of firms per day & 2,342 & 2,342 & 1,013 & 1,005 \\
\hline Avg. adj. $R^{2}$ & 0.045 & 0.045 & 0.021 & 0.015 \\
\hline
\end{tabular}

measure returns, and when we exclude low-price stocks. This behavior is also ubiquitous across NASDAQ and NYSE stocks, small and large stocks, growth and value stocks, and momentum winners and losers, although there is a larger mean overnight return and trading day reversal for small stocks, NASDAQ stocks, growth stocks, and momentum losers. We also find that these patterns are larger in magnitude on Mondays, but they are also present on the other days of the week. In addition, these results appear in all subperiods, though they decline in magnitude over time, perhaps due to regulatory changes and technological advances, such as decimalization in 2001 and the subsequent expansion of algorithmic trading.

\section{B. Fama-MacBeth Regression Analysis}

In this section we examine whether our results are robust to alternative methodology, by applying regression analysis based on the following model: ${ }^{28}$

(1) $\mathrm{CTO}_{i t}\left(\mathrm{OTC}_{i t}\right)=a_{0}+a_{1} \mathrm{ATTENTION}_{i t}+a_{2} \mathrm{INST}_{i t}+a_{3} \mathrm{SIZE}_{i t}+\varepsilon_{i t}$,

where ATTENTION $_{i t}=$ each proxy for retail investor attention $\left(\right.$ VOL $_{t-1}$ or RETAIL_NETBUY $\left.{ }_{t-1}\right)$,

$\mathrm{INST}_{i t}=$ the firm's percentage institutional ownership from the previous quarter,

$\mathrm{SIZE}_{i t}=$ the firm's mean market capitalization over the previous 20 trading days.

In this analysis, the dependent variables are winsorized to eliminate outliers beyond $1 \%$ in the tails. In addition, the independent variables are replaced with

\footnotetext{
${ }^{28}$ We have also included the firm's effective half spread and relative short interest in model (1), with robust results.
} 
their decile ranks, adjusted to range between -0.5 and +0.5 . This rank regression approach attenuates the influence of outliers. ${ }^{29}$

First, for every day $(t)$ in the sample period, we estimate model (1) for the cross section of stocks $(i)$, using each dependent variable (CTO or OTC). Second, we compute the time-series mean coefficients across all days $(t)$ in the sample period. The standard errors of these Fama-MacBeth (1973) mean coefficients are used to construct the $t$-ratios.

Results appear in Panel B of Table 5. They show that the overnight return is positively related to each proxy for retail investor attention yesterday, and negatively related to the firm's institutional ownership. Likewise, the trading day reversal is negatively associated with each attention proxy and positively related to institutional ownership. Consistent with our theory of attention-based overpricing at the open, these results imply a larger overnight return and trading day reversal for stocks that are subject to higher levels of retail investor attention yesterday, along with greater limits to arbitrage embodied in lower institutional ownership. These results also reveal that smaller firms tend to have a larger trading day reversal. We conclude that our evidence and its implications are not dependent upon the research methodology applied.

\section{Summary and Conclusions}

This paper investigates the role of attention as a potential source of retail investor sentiment, and examines whether attention-based retail trading causes prices to temporarily deviate from fundamental values at the open of the typical trading day. We show that high-attention days for individual stocks are followed by high net retail buying at the start of the next trading day. Moreover, this increased retail buying pressure results in opening prices that tend to be high relative to prices during the rest of the trading day. Furthermore, we find that these predictable intraday price patterns are more pronounced for stocks that are difficult to value and costly to arbitrage, and they are larger in magnitude during periods of high investor sentiment.

This study is the first to examine intraday patterns in retail trading and price formation in relation to investor sentiment, proxied by retail investor attention. By investigating our theory of attention-based overpricing at the open, we uncover and help resolve a heretofore unexplained intraday price anomaly: Stocks that have recently attracted the attention of retail investors have a strong tendency for net retail buying at the open, which leads to high opening prices and positive returns during the overnight period, followed by reversals during the subsequent trading day.

Our results should be of interest to investors and regulators alike. During periods of high investor sentiment, a strategy of selling high-attention stocks at the open and delaying purchases until later in the trading day can yield significant improvements to performance. This evidence shows that some retail investors bear substantive hidden costs, through their penchant for buying stocks at inflated

\footnotetext{
${ }^{29}$ Similar results are obtained when the analysis is applied to the original data.
} 
prices during the 1 st hour of trading following high-attention days. During periods of high investor sentiment, for example, the implicit costs of buying highattention stocks at the start of the day can be twice the effective half spread. The 1st step toward reducing this hidden cost of buying high-attention stocks at the open is to enhance awareness among retail traders of the potentially detrimental price impact of such trading activity.

\section{References}

Acharya, V. V., and L. H. Pedersen. "Asset Pricing with Liquidity Risk." Journal of Financial Economics, 77 (2005), 375-410.

Almazan, A.; K. C. Brown; M. Carlson; and D. A. Chapman. "Why Constrain Your Mutual Fund Manager?" Journal of Financial Economics, 73 (2004), 289-321.

Asquith, P.; P. A. Pathak; and J. R. Ritter. "Short Interest, Institutional Ownership, and Stock Returns." Journal of Financial Economics, 78 (2005), 243-276.

Baker, M., and J. Wurgler. "Investor Sentiment and the Cross-Section of Stock Returns." Journal of Finance, 4 (2006), 1645-1680.

Baker, M., and J. Wurgler. "Investor Sentiment in the Stock Market." Journal of Economic Perspectives, 21 (2007), 129-152.

Barber, B. M., and T. Odean. "All that Glitters: The Effect of Attention and News on the Buying Behavior of Individual and Institutional Investors." Review of Financial Studies, 21 (2008), 785818.

Barber, B. M.; T. Odean; and N. Zhu. "Do Retail Trades Move Markets?" Review of Financial Studies, 22 (2009), 151-186.

Barclay, M. J., and T. Hendershott. "Price Discovery and Trading After Hours." Review of Financial Studies, 16 (2003), 1041-1073.

Barclay, M. J., and T. Hendershott. "Liquidity Externalities and Adverse Selection: Evidence from Trading After Hours." Journal of Finance, 59 (2004), 681-710.

Berkman, H.; V. Dimitrov; P. C. Jain; P. D. Koch; and S. Tice. "Sell on the News: Differences of Opinion, Short Sale Constraints, and Returns around Earnings Announcements." Journal of Financial Economics, 92 (2009), 376-399.

Bernard, V. L. "Cross-Sectional Dependence and Problems in Inference in Market-Based Accounting Research." Journal of Accounting Research, 25 (1987), 1-48.

Bessembinder, H. "Issues in Assessing Trade Execution Costs." Journal of Financial Markets, 6 (2003), 233-257.

Branch, B., and A. Ma. "The Overnight Return, One More Anomaly." Working Paper, University of Massachusetts, available at http://ssrn.com/abstract $=937997$ (2008).

Cliff, M.; M. Cooper; and H. Gulen. "Return Differences between Trading and Non-Trading Hours: Like Night and Day." Working Paper, University of Utah, available at http://papers.ssrn.com/sol3/ papers.cfm?abstract_id=1004081\#PaperDownload (2008).

D'Avolio, G. "The Market for Borrowing Stock." Journal of Financial Economics, 66 (2002), 271-306.

De Long, J. B.; A. Shleifer; L. H. Summers; and R. J. Waldmann. "Noise Trader Risk in Financial Markets." Journal of Political Economy, 98 (1990), 703-738.

Fama, E. F., and J. D. MacBeth. "Risk, Return, and Equilibrium: Empirical Tests." Journal of Political Economy, 81 (1973), 607-636.

Gompers, P. A., and A. Metrick. "Institutional Investors and Equity Prices." Quarterly Journal of Economics, 116 (2001), 229-259.

Griffin, J. M.; J. H. Harris; and S. Topaloglu. "The Dynamics of Institutional and Individual Trading." Journal of Finance, 58 (2003), 2285-2320.

Kumar, A., and C. M. C. Lee. "Retail Investor Sentiment and Return Comovements." Journal of Finance, 61 (2006), 2451-2486.

Lee, C. M. C., and M. J. Ready. "Inferring Trade Direction from Intraday Data." Journal of Finance, 46 (1991), 733-746.

Nagel, S. "Short Sales, Institutional Investors and the Cross-Section of Stock Returns." Journal of Financial Economics, 78 (2005), 277-309.

Newey, W. K., and K. D. West. "A Simple, Positive Semi-Definite Heteroskedasticity and Autocorrelation Consistent Covariance Matrix." Econometrica, 55 (1987), 703-708.

Odean, T. "Do Investors Trade Too Much?” American Economic Review, 89 (1999), 1279-1298. 
Ofek, E.; M. Richardson; and R. F. Whitelaw. "Limited Arbitrage and Short Sales Restrictions: Evidence from the Options Markets." Journal of Financial Economics, 74 (2004), 305-342.

Pastor, L., and R. F. Stambaugh. "Liquidity Risk and Expected Stock Returns." Journal of Political Economy, 111 (2003), 642-685.

Sadka, R., and A. Scherbina. "Analyst Disagreement, Mispricing, and Liquidity." Journal of Finance, 62 (2007), 2367-2403.

Shleifer, A., and R. W. Vishny. “The Limits of Arbitrage.” Journal of Finance, 52 (1997), 35-55. 
Copyright of Journal of Financial \& Quantitative Analysis is the property of Cambridge University Press and its content may not be copied or emailed to multiple sites or posted to a listserv without the copyright holder's express written permission. However, users may print, download, or email articles for individual use. 